\title{
IN A FRAGILE STATE: \\ THE CONSERVATION AUTHORITIES BRANCH PHOTOGRAPH ALBUMS AT THE ARGHIVES OF ONTARIO
}

\author{
by \\ Ross Knapper, BS, Environmental Science, Minnesota State University, 1999 \\ BS, Ecology, Minnesota State University, 1999
}

\author{
An applied thesis project \\ presented to Ryerson University and George Eastman House \\ in partial fulfillment of the \\ requirements for the degree of \\ Master of Arts \\ in the program of \\ Photographic Preservation and Collections Management
}

Toronto, Ontario, Canada, 2013

(C) Ross Knapper 2013 
I hereby declare that I am the sole author of this thesis. This is a true copy of the thesis, including any required final revisions, as accepted by my examiners.

I authorize Ryerson University and George Eastman House to lend this thesis to other institutions or individuals for the purpose of scholarly research.

I further authorize Ryerson University and George Eastman House to reproduce this thesis by photocopying or by other means, in total or in part, at the request of other institutions or individuals for the purpose of scholarly research.

I understand that my thesis may be made electronically available to the public

\section{Ross Knapper}


In a Fragile State:

The Conservation Authorities Branch Photograph Albums at the Archives of Ontario

Master of Arts, 2013

Ross M. Knapper

Photographic Preservation and Collections Management

Ryerson University/George Eastman House

\section{Abstract}

The preservation of a large volume of objects is often an examined compromise between the very best options available and appropriate allocation of resources. What, where, and how do institutions make the decisions necessary to properly preserve materials while accounting for constraints in available expertise, resources, funding, and institutional needs? Utilizing a collection of sixty acidic and fragile scrapbook-style albums held by the Archives of Ontario, this applied thesis project discusses preservation options suitable to photographic albums and scrapbooks, and explores the decision-making process required to develop a working method to restore access to the sixty Conservation Authorities Branch albums, which are currently inaccessible due to preservation concerns. While specific to the resources available at the Archives of Ontario, the basic methodology is applicable to a range of institutions both large and small. 


\section{Acknowledgments}

I would like to first thank my thesis advisor, Dee Psaila, for her unending support through the thesis process, for her willingness to share her knowledge and experience with me, and for being an invaluable mentor to me for the past year. A great deal of appreciation is expressed to my second reader, Vid Ingelevics, for his additional comments and advice. I also wish to extend my gratitude to Shannon Coles, conservator at the Archives of Ontario, for providing technical assistance and advice, and patiently listening as I assailed her with daily questions. Furthermore, I would like to acknowledge professor David Harris for his initial guidance and assistance with the project, along with the rest of the faculty at Ryerson University, from whom I have learned a great deal in the past two years.

To my wife Stacy, thank you for always believing in me; and finally, to my son Shin-Yoo, thank you for making me smile, and for reminding me about the important things in life. 


\section{Table of Contents}

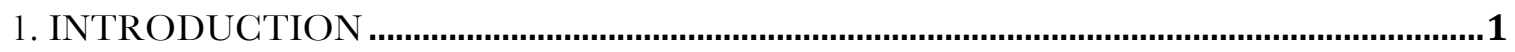

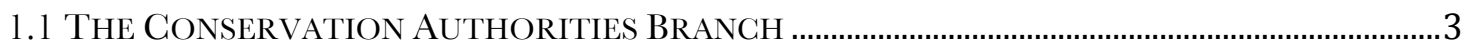

1.2 The CONSERVATION AUTHORITIES BRANCH PHOTOGRAPH ALBUMS ..................................

2. LITERATURE SURVEY

3. METHODOLOGY

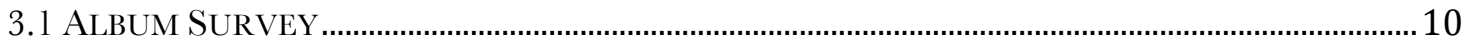

3.2 GASE STUDY ALBUM SELECTION AND PRE-TREATMENT CONDITION REPORT ...................13

3.3 PRESERVATION OPTIONS AND ANALYSIS.......................................................................................

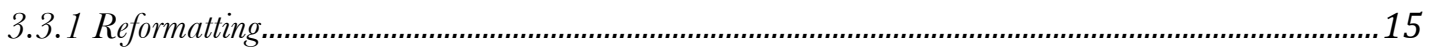

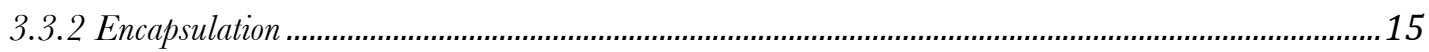

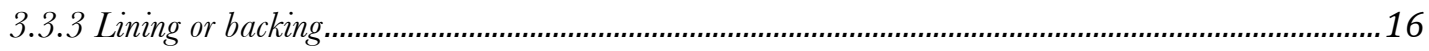

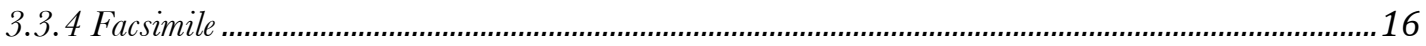

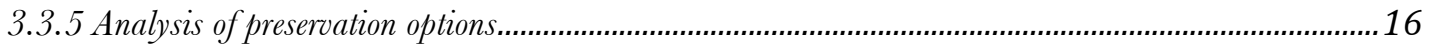

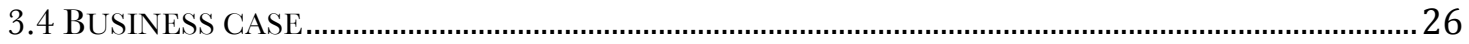

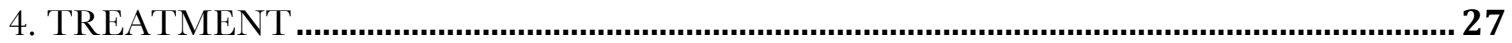

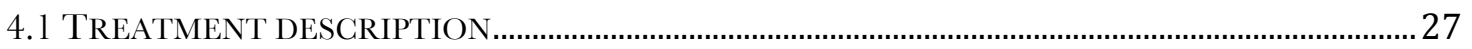

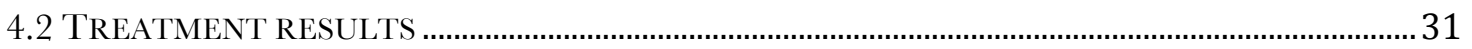

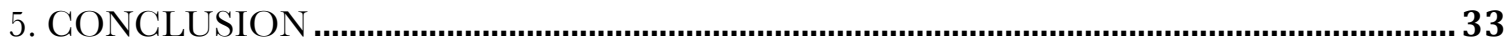

APPENDIX A: RESULTS OF 2013 ALBUM SURVEY ................................................................. 35

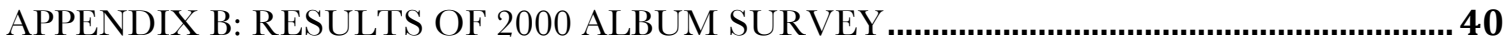

APPENDIX C: CONDITION REPORT ............................................................................. 44

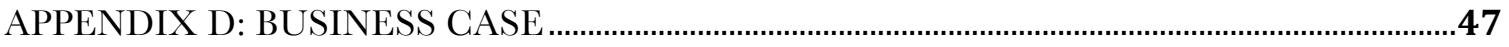

APPENDIX E: FLOWCHART FOR DETERMINING TREATMENT.........................................58

APPENDIX F: PREPARATION OF METHYL GELLULOSE.......................................................60

APPENDIX G: LIST OF MATERIALS AND SUPPLIERS..........................................................62

BIBLIOGRAPHY 


\section{List of Figures}

Figure 1: Exterior view of one of the $\mathrm{CAB}$ photograph albums

Figure 2: Illustration of the post-binding structure of albums

Figure 3: Example of general layout of albums

Figure 4: Example of general layout of albums

Figure 5: Example of page content showing tipped in watershed map

Figure 6: Sheet music and lyrics to a conservation themed song

Figure 7: Photographs of a tower used to take other photographs from

Figure 8: Album page showing photographs of agricultural land

Figure 9: Photographs of speakers at the opening of the Fanshawe Dam

Figure 10: Screenshot of the album survey form

Figure 11: View of the workstation set up for surveying the albums

Figure 12: Example of page separating from spine

Figure 13: Another example of page separation

Figure 14: Example of staining from pressure sensitive tape

Figure 15: Example of a torn album page

Figure 16: Image of the Ausable River album showing extensive page deterioration

Figure 17: Interior view of Ausable River album showing envelopes filled with broken pages

Figure 18: Condition photograph of RG 1-112-1-0-47

Figure 19: Illustration showing the size and number of albums

Figure 20: Example of photograph with no negative

Figure 21: Example of scrapbook elements within albums

Figure 22: Illustration showing the limiting nature of the post-binding structure

Figure 23: Illustration showing the stress points between mounted photographs

Figure 24: View of the ultrasonic welder used for encapsulation

Figure 25: Example of encapsulated page

Figure 26: Album page 37 after encapsulation and re-consolidated

Figure 27: Album page 37 prior to encapsulation and in multiple pieces

Figure 28: View of workstation set up for hinging pages

Figure 29: Example of V-hinge used for hinging pages

Figure 30: Example of hinged page

Figure 31: Additional example of hinged page

Figure 32: Box 1 of completed RG 1-112-1-0-47

Figure 33: View of RG 1-112-1-0-47 post-treatment 


\section{Appendices}

Appendix A: Results of 2013 album survey

Appendix B: Results of 2000 album survey

Appendix C: Condition report for RG 1-112-1-0-47

Appendix D: Business Case

Appendix E: Flowchart for determining encapsulation or hinging of album page

Appendix F: Preparation of methyl cellulose adhesive

Appendix G: List of materials and suppliers 


\section{Introduction}

The photograph album is a commonly used format for the accumulation and dissemination of photographs, and examples of early photograph albums can be traced to the very inception of photography. ${ }^{1}$ An album is generally considered to be a bound structure consisting of blank pages in a book format that is either handmade or purchased, and then filled with photographs by the owner of the album. Albums are often associated with the term scrapbook as they share many common features, functions, and materials, with scrapbooks typically containing non-photographic elements, such as newspaper clippings, documents or other ephemera as well as photographs. Albums enable photographs to be easily stored, viewed, and organized into a cohesive narrative or sequence. They are often organized around a theme, subject, chronologically, or a combination of the three. While use of physical albums has generally declined with the advent and increasing popularity of digital photography and digital albums, many digital albums still mimic these functions, evidencing the effectiveness of the album concept, even in the digital age.

Albums can have artifactual, artistic, historic, or informational significance. Because they are individually created, they are also a unique record of the person, family, or organization that created them, making them valuable primary source documents and a lens with which to view the past, and are therefore often found in the holdings of archives, as well as museums, and libraries. While unique in their creation and often

1 The Hippolyte Bayard album in the collection of the Société Française de photographie dates to 1839 and contains test prints of his direct positive printing process. The Album di Disegni Fotogenici in the collection of the Metropolitan Museum of Art was assembled in 1839-1840 by Antonio Bertoloni, an Italian botanist and friend of William Henry Fox Talbot. It contains photogenic drawings sent during regular correspondence between Talbot and Bertoloni, and contains the first examples of photogenic drawings created in Italy by Italian chemist Tassinari. 
meant as keepsakes or enduring records of an event, people, or time period, albums in general share some typical traits, and are susceptible to damage and deterioration from a myriad of similar factors. Damaged bindings, pages that are broken or torn, cockling from adhesives, paper discoloration, and brittle paper are just a sample of the many ways in which albums deteriorate. Deterioration is often the result of improper handling, poor storage conditions, inappropriate binding methods, and overuse. Unsuitable construction materials, such as acidic wood-pulp paper however, is frequently one of the most common factors leading to deterioration. As the acidic paper degrades, the paper fibers weaken, become embrittled, and discolour, as is the case with the Conservation Authorities Branch photograph albums held in the collection of the Archives of Ontario and used as the basis of this thesis.

The Conservation Authorities Branch (CAB) photograph albums consist of sixty photograph albums, and are typical of many album constructions. The albums were assembled using commercially available products that were manufactured from low quality materials. The pages for the albums contain acidic wood-pulp paper that has degraded over time, resulting in embrittled pages, making access to the albums difficult without causing further deterioration, and physical damage to the albums and subsequent photographs. Because of this, access to the GAB photograph albums has been closed to the public since 2000. However, as a public archive, the mandate of the Archives of Ontario $(\mathrm{AO})$ is "to provide access to the public to records in the custody or control of the Archives of Ontario."2 The large number of albums within the series, and the overall scale of the project provide a difficult balance between providing access to the albums and

\footnotetext{
2 "Archives Record Keeping Act, 2006," lasted modified June 25, 2013. http://www.e-laws.gov.on.ca/html/statutes/english/elaws_statutes_06a34_e.htm\#BK8
} 
efficient management of staff and resources. With this in mind, the focus of the research is to develop a working method to preserve and facilitate access to the Conservation Authorities Branch photograph albums. Due to the scope of the thesis, the working method will be completed on one photograph album as a test case study for evaluation of the preservation treatment.

\subsection{The Conservation Authorities Branch}

The Conservation Authorities Branch was a provincial agency created to facilitate the activities of local conservation authorities in Ontario. The local conservation authorities in turn, were charged with the conservation and management of water resources within their designated watershed boundary. The CAB provided assistance to local conservation authorities by conducting surveys; offering technical assistance with flood management, land use, forestry, and wildlife; recommending conservation programs; and assisting with grant processes. Established on January 1, 1962 as a division within the Ontario Department of Lands and Forests, the CAB subsumed the former duties of the Conservation Branch of the Department of Planning and Development (1947-1961), and was itself later transferred to the Department of Energy and Resources Management in 1964, and subsequently merged in 1979 with the Engineering Services Branch to form the Conservation Authorities and Water Management Branch, a branch within the Ontario Ministry of Natural Resources. ${ }^{3}$

\subsection{The Conservation Authorities Branch photograph albums}

The Conservation Authorities Branch photograph albums consist of sixty

\footnotetext{
3 Archives of Ontario. "Conservation Authorities Branch.” Accessed January 3, 2013. http://ao.minisisinc.com/scripts/mwimain.dll/401/AUTH_JOIN/REFA/CA1050?JU MP
} 
photograph albums assembled by the CAB between the years 1947-1965. The Archives of Ontario acquired the albums, officially referenced as sub-series RG 1-112-1, in 1976 through a scheduled transfer from the Ministry of Natural Resources. As seen in Figures 1 and 2, the albums employ a post binding design, are hard-covered with paper or leather,
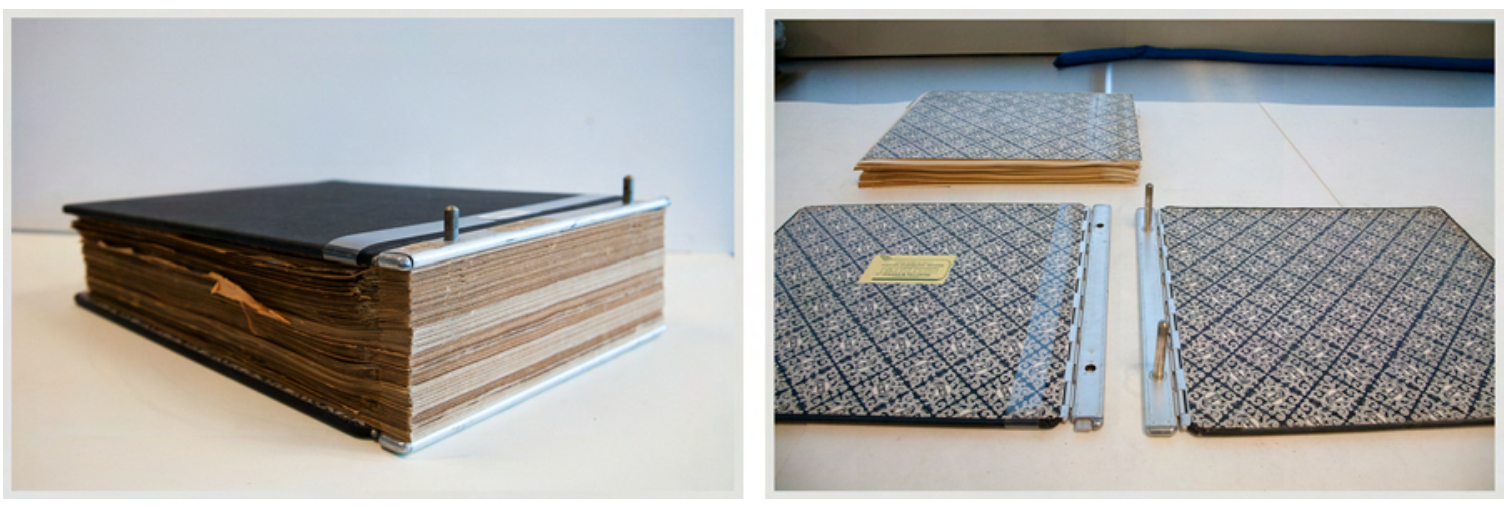

Figures 1 and 2 (L to $\mathrm{R}$ ): Exterior view of one of the CAB photograph albums. Illustration showing the post-binding structure of the albums.

and are constructed from commercially manufactured "Vulcan Automatic Binders, Model No. B-60,” available from retailer Grand \& Toy. They have consistent length and width dimensions of $37.5 \mathrm{~cm} \times 45.5 \mathrm{~cm}$, and vary in height from $3.4 \mathrm{~cm}$ to $17.3 \mathrm{~cm}$, with an average height of $8.25 \mathrm{~cm}$. Each album contains approximately 600-700 tipped-in gelatin silver prints with accompanying printed or hand-written labels (see Figures 3 and 4).

Labels generally include a caption or description of the photograph, along with a negative
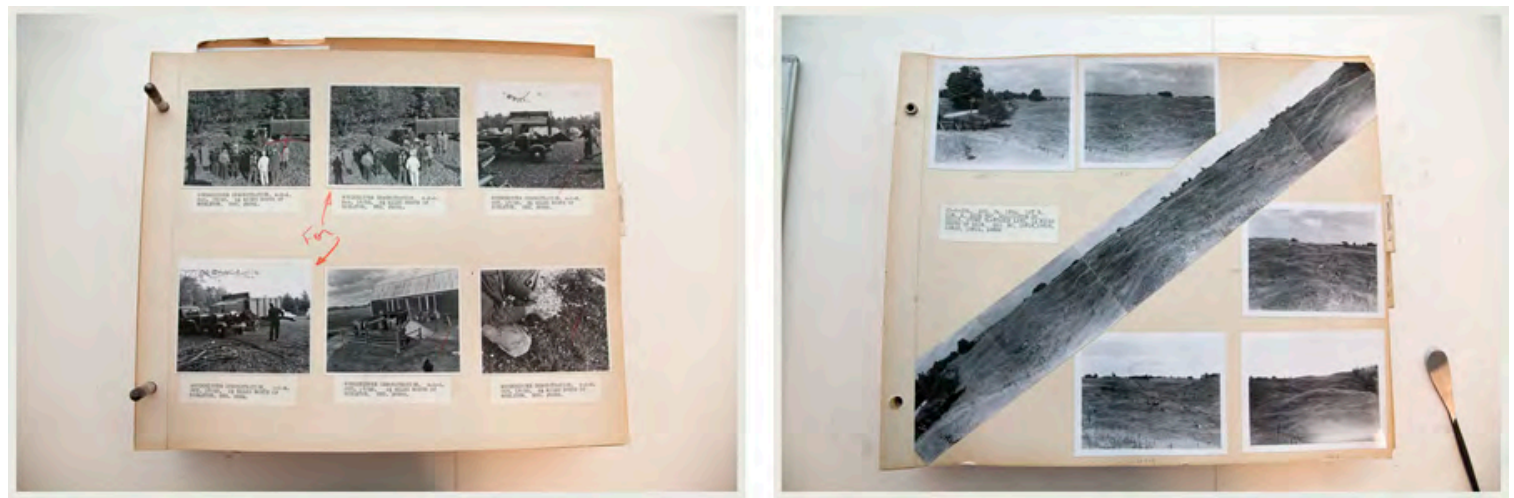

Figures 3 and 4 ( $\mathrm{L}$ to $\mathrm{R}$ ): Examples of the general layout of the albums. 
number if available. Several albums also contain non-photographic material such as maps, brochures, and even sheet music to a conservation theme song (see Figures 5-9). The albums currently function as a visual index to approximately 46,600 photographs and negatives. This sub-series of negatives and prints, referenced as RG 1-112-2, was collected or created during surveys of river drainage systems in Ontario conducted by the CAB between 1947-1965. The photographs comprise views of rivers and their surrounding lands, historic flood events, local flora and fauna, and examples of commercial and recreational land uses. Intended for inclusion in reports and publications, the photographs were used to promote soil and water conservation practices and the establishment of local watershed authority boards, as well as documenting tours and public displays. The photographs also record the activities of local conservation authority boards such as the construction of recreational parks and water control facilities.
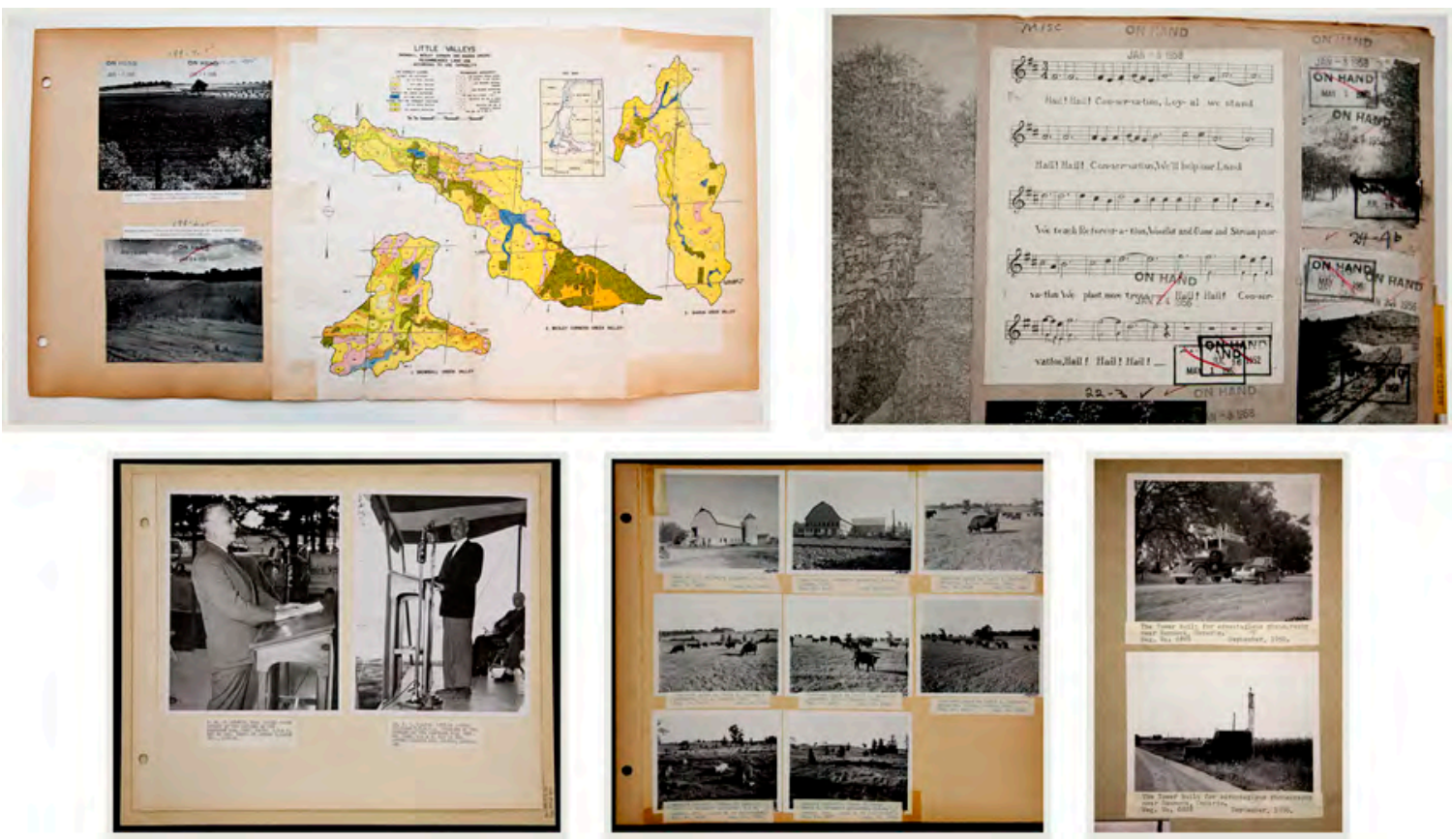

Figures 5-9 (clockwise L to R): Examples of album content showing: photographs and tipped in watershed map, sheet music and lyrics to a conservation themed song, photographs of the tower used to take other photographs, views of agricultural land, speakers at the opening of the Fanshawe Dam. 


\section{Literature Survey}

Research into preservation options suitable to photographic albums and scrapbooks provided a variety of sources with which to start the project. The Library of Congress's "Preservation of Scrapbook and Album Formats" is a digital version of the Library of Congress 1991 Preservation Basics informational leaflet, which includes preservation recommendations such as environmental controls, physical storage, handling, and physical reformatting. Similarly, "Preservation Options for Scrapbook and Album Formats" (1991), by Sherelyn Ogden discusses the various types of deterioration common to scrapbooks and albums, and presents considerations, such as whether the album has informational value or artifactual value, when considering the type of treatment options. Lastly, Jennifer Hain Teper's “Introduction to Preservation Challenges and Potential Solutions for Scrapbooks in Archival Collections” (2007), intended for an archival audience, focuses on scrapbook composition, common forms of deterioration, preservation options, and advantages and limitations to treatment and reformatting options. These representative texts were used to evaluate the different forms of deterioration found in the $\mathrm{CAB}$ photograph albums, and provided the basis for initial testing and relevant consideration when evaluating preservation options, as well as advising on forms of deterioration common to photograph albums.

In addition to preservation guidelines and recommendations, two case-study reports of previous album treatments were reviewed to analyze the effectiveness of the chosen methods. "Images of the Southwest: A Tourist Album" (1999) by Laura Downey, published in the postprints of the $27^{\text {th }}$ annual meeting of the American Institute for Conservation of Historic and Artistic Works, details the treatment of a 1900 photographic album constructed to commemorate a trip to Arizona and New Mexico. The album 
suffered from a detached cover, and acidic paper pages that had begun to detach from the binding, but the photographs themselves remained in stable condition. The CAB photograph albums mirror similar conditions, such as presence of acidic paper, torn and detached pages, and photographs that seem largely unaffected by deterioration of the album pages. "The Conservation of a Photograph Album at the National Archives of Canada" (1991) by Gregory Hill and published in the Journal of the American Institute for Conservation, highlights the treatment performed on The Jacobs Album, a highly valued nineteenth-century album. While the conservation treatment ultimately carried out on The Jacobs Album is beyond the scope of the PPGM program, and therefore was not a viable option for this project, the article also provides a discussion of all treatment options considered, and the decision-making process leading to the chosen treatment method, which was of value when considering treatment options for the CAB albums. Determining the most appropriate preservation option for the CAB photograph albums requires the consideration of a myriad of intellectual factors - from archival theory and appraisal to visual and material culture - in addition to technical preservation knowledge. In What are Archives? Cultural and Theoretical Perspectives: A Reader (2008) edited by Louise Craven, the theoretical and cultural roles of archives are explored through a series of essays that focus on the importance of the archive and the archivist in the context of twenty-first-century culture and technology. This includes essays on developments in the archival paradigm, identity and culture in archives, the impacts of digital technology and the Internet, and archival use and users. Gregory Hunter's 2003 Maintaining Practical Archives: A How-to-do-it Manual includes additional discussion on what archives are, the archival mission, differences between libraries and archives, and a brief history of archives. What are Archives? and Maintaining Practical Archives serve to provide a basic 
understanding of archives, and help situate the role and function of archives in the context of access and preservation of records.

Norman Charbonneau's 2005 essay "The Selection of Photographs” discusses archival appraisal as it specifically relates to photographs, including considerations of creator intent. The article also contains case studies designed to assist with the implementation of the appraisal methods discussed. Photographs: Archival Care and Management (2006) by Mary Lynn Ritzenthaler and Diane Vogt-O’Conner serves as a how-to manual designed to guide mainly archives, but also libraries and other institutions, in the preservation and use of photographs. It includes useful chapters on the varied uses of photographs in archival collections, how to read and research photographs, photographic appraisal, and preservation recommendations. While beneficial as a general information guide, Photographs: Archival Care and Management, along with "The Selection of Photographs" provide a framework with which to assess the archival and research value of the CAB photograph albums.

Like many institutions, the Archives of Ontario has begun the digitization of its records, and reformatting by means of digitization is one of several preservation options often cited in recommendations for albums and scrapbooks. Digitization however is not without its disadvantages. High costs, data corruption, future readability, migration, and loss of material culture are a few of the current concerns with digitization. In the introduction to Photographs Objects Histories: On the Materiality of Images (2004) editors Elizabeth Edwards and Janice Hart stress the importance of the photograph as a physical object and suggest ways to use the materiality and physicality of an object when conducting historical research. Joanna Sassoon in her essay "Photographic Materiality in the Age of Digital Reproduction," published in Photographs Objects Histories, expands upon 
this idea by discussing some of the potential pitfalls associated with the digitization of photographs, how the loss of materiality often changes the manner in which photographs are viewed and interpreted, and how the meaning of photographs can change once they have become digitized. Similarly, in "Material Literacy: Reading Records as Material Culture" (2005) Ala Rekrut argues for the importance of viewing archival records as material culture, suggesting that evidence of creation and change (deterioration, wear from use, alterations by custodians) has a significant impact on the future interpretation of the records. The introduction to Photographs Objects Histories, "Photographic Materiality in the Age of Digital Reproduction," and "Material Literacy" provide a backdrop with which to assess the role and importance of material culture and archival records when evaluating preservation options for the $\mathrm{CAB}$ photograph albums.

While resources for the preservation of albums and scrapbooks are available in a variety of forms and from a host of respected sources and institutions, the dual nature of photograph albums, being ubiquitous in numbers and individual in their creation, results in recommendations being either too generalized or too specific for direct application to the $\mathrm{CAB}$ photograph albums. In addition, preservation and treatment options generally address the treatment of single albums or albums of high monetary value. No sources have been located to date that undertake the preservation of a large number of albums such as the sixty $\mathrm{CAB}$ photograph albums. The scale of the CAB photograph album project necessitates a preservation approach that is not only effective, but also efficient. Evaluation of applicable preservation techniques needs to be combined with considered thought into the original intent of the albums, the anticipated needs of future researchers, the requirements of the Archives of Ontario, and the resources available. 


\section{Methodology}

\subsection{Album Survey}

In addition to reviewing the existing information in the collection file of RG 1112-1 to educate myself on the collection's creation, acquisition, and administrative history, preliminary work for the thesis began by completing a survey of all sixty CAB photograph albums. The survey served three purposes: 1) to familiarize myself with the albums in general, and assess the current condition of the albums as the survey was not intended to be a comprehensive condition report on each album, but designed to identify the various preservation issues affecting the albums in whole, 2) to provide a rationale for selection of the case study album for the project, and 3) to group and prioritize the remaining albums for future treatment. Basic information collected during the survey
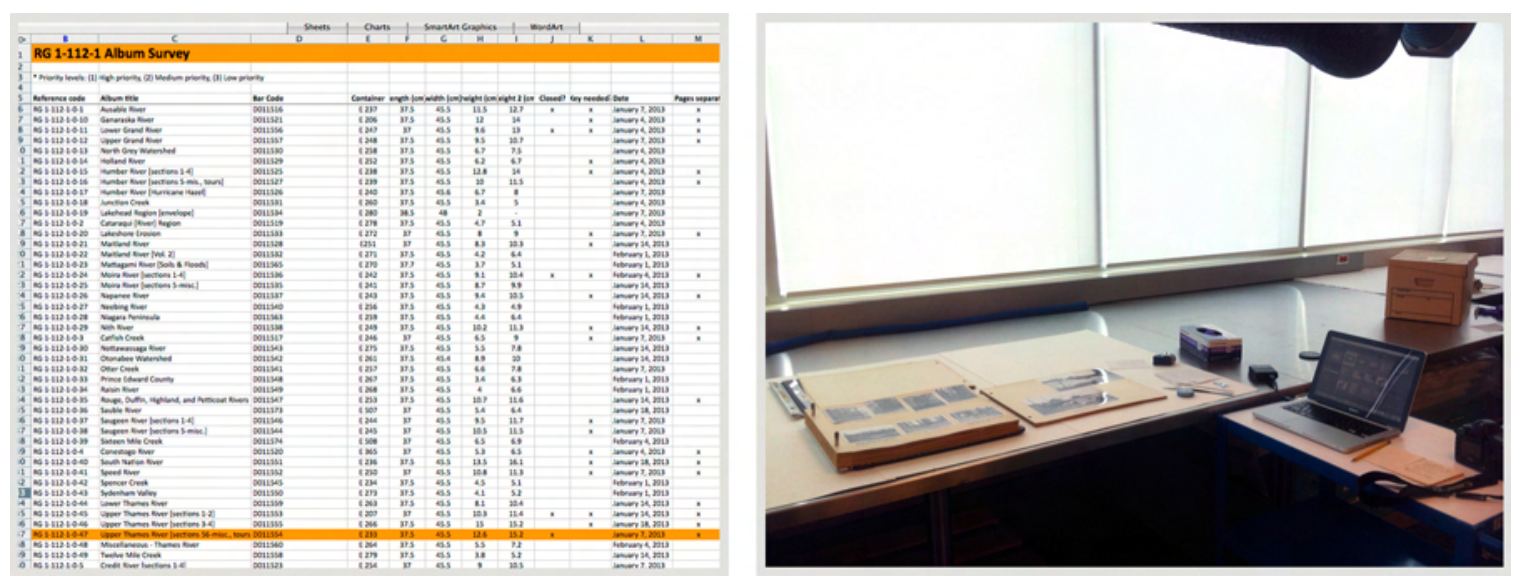

Figures 10 and 11 (L to R): Screenshot of the album survey form. View of the workstation set up for surveying the albums.

included album name, reference code, container number, dimensions, if pages were separated from the binding and the approximate percentage of such separation in $25 \%$ increments, if pages were cracked or ripped and the approximate percentage of such damage, and a brief description of preservation concerns. Lastly a priority rating of 1-3 was assigned to each album, with 1 indicating high priority, and 3 indicating low priority. 
Priority ratings were based on the presence or absence of pages separated from the binding, and the percentage of separated, cracked, or torn pages. To facilitate access and use of the survey results by the $\mathrm{AO}$ for future projects, information was recorded using Microsoft Excel (see Figure 10), which was consistent with AO standards. Results of the survey can be found in Appendix A.

Typical signs of deterioration within the $\mathrm{CAB}$ photograph albums consisted of pages that were separated from the binding, broken into multiple pieces, torn, chipped, cockled, or had overall discolouration. Many albums also contained pressure sensitive
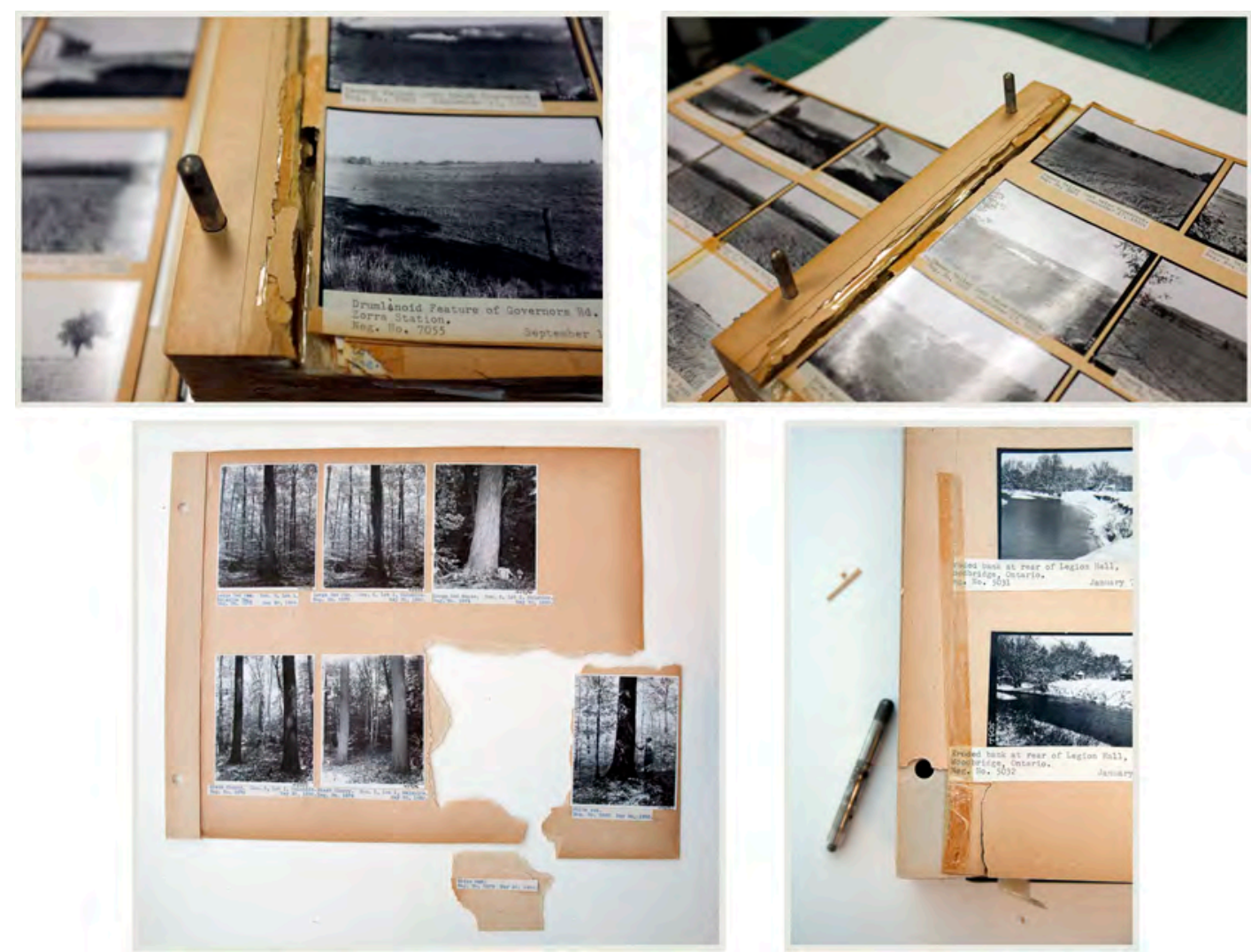

Figures 12-15 (Clockwise L to R): Two views of page separating from the spine. Staining from adhesive tape. Torn album page with two remaining fragments.

tape, often used (unsuccessfully) to repair or reinforce the binding edge of the page.

Minimal silver mirroring and image fading was noted on a small percentage of 
photographs, and aside from physical damage from being near broken or torn pages, the photographs remained relatively unaffected by album deterioration. The album pages were themselves the largest point of concern.

Results from the survey showed that twenty three of the albums were in "poor" condition, being in the advanced stages of deterioration and in need of immediate preservation treatment to make them accessible; three albums were in "fair" condition, requiring treatment as resources become available; and thirty-three albums were considered to be in "stable" condition, with potential to be re-opened for access with strict care and handling instructions. In addition, one album, The Ausable River Album (RG 1-112-1-0-1), was so poorly deteriorated that preservation is not possible (see Figures 16 and 17). The interior of the album contains a large quantity of paper and photograph
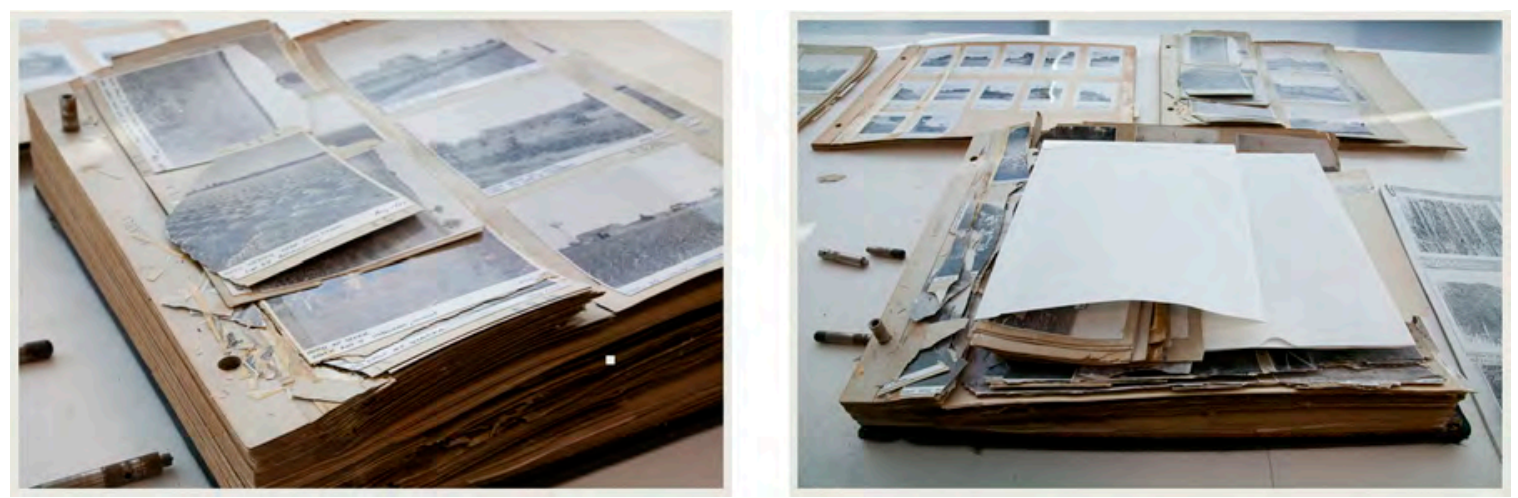

Figures 16 and 17 (L to R): Image of the Ausable River album showing extensive page deterioration. Interior view of Ausable River album showing envelopes filled with broken pages.

fragments, a high percentage of separated pages and broken pages, and two envelopes located near the centre of the album contain remnants of several dislodged pages. Full conservation by a conservator would be required to make this album accessible, and even then, consolidation of the photograph fragments would be time consuming and require a great deal of resources with questionable and limited results. Much of the content and 
information would likely be missing due to losses in the photographs, resulting in a record with minimal archival value. The Ausable River album serves as a potent reminder of the eventual fate of the remaining $\mathrm{CAB}$ photograph albums if left untreated.

Upon completion of the current album survey, a prior survey of the albums undertaken in 2000 by a previous $\mathrm{AO}$ archivist was discovered, and allowed for comparison with the results of the recent 2013 survey. While criteria for establishing the different album conditions were not included with the 2000 survey results, and therefore direct comparison of the results could not be performed, interpretation of the results provides reasonable correlations between the surveys and elucidates the rates of album deterioration. For example, in the 2000 survey thirty-four albums were classified as in "good" condition, compared to thirty-three noted as "stable" in the 2013 survey. In 2000, six albums were labeled as "close" (sic), with an additional seven listed as "poor" condition, and twelve identified as in "fair" condition. One album, RG 1-112-1-0-52, was not given a condition classification. Accepting that "close" and "poor", and "good" from the 2000 survey correlate with "poor" and "stable" respectively from the 2013 survey, it is evident that the largest percentage of change in deterioration occurred in the category marked "fair" in both surveys, with a high percentage of "fair" albums deteriorating rapidly to "poor" condition from 2000 to 2013 . The 2000 survey can be found in Appendix B.

\subsection{Case study album selection and pre-treatment condition report}

Utilizing the results of the album survey, RG 1-112-1-0-47, the Thames River album was chosen to serve as the case study album. While several albums were suitable for use as the case study, RG 1-112-1-0-47 was chosen based on several factors: the 
album was one of the original albums listed for closure in the 2000 survey, and therefore is representative of an album in an advanced state of deterioration; the album is typical of the type of deterioration common to the $\mathrm{CAB}$ photograph albums including pages separated from the binding, broken pages, torn and chipped pages, page discolouration, and cockling; the size of the album is slightly larger than the average, was not only suitable to the scope of the project, but also provided a reasonable assessment of the time and resources required to complete treatment on an album for future project planning. After selection, a pre-treatment condition report of the Thames River album was completed, along with photo-documentation of the album (see Figure 18). A copy of the pre-treatment condition report is located in Appendix C.

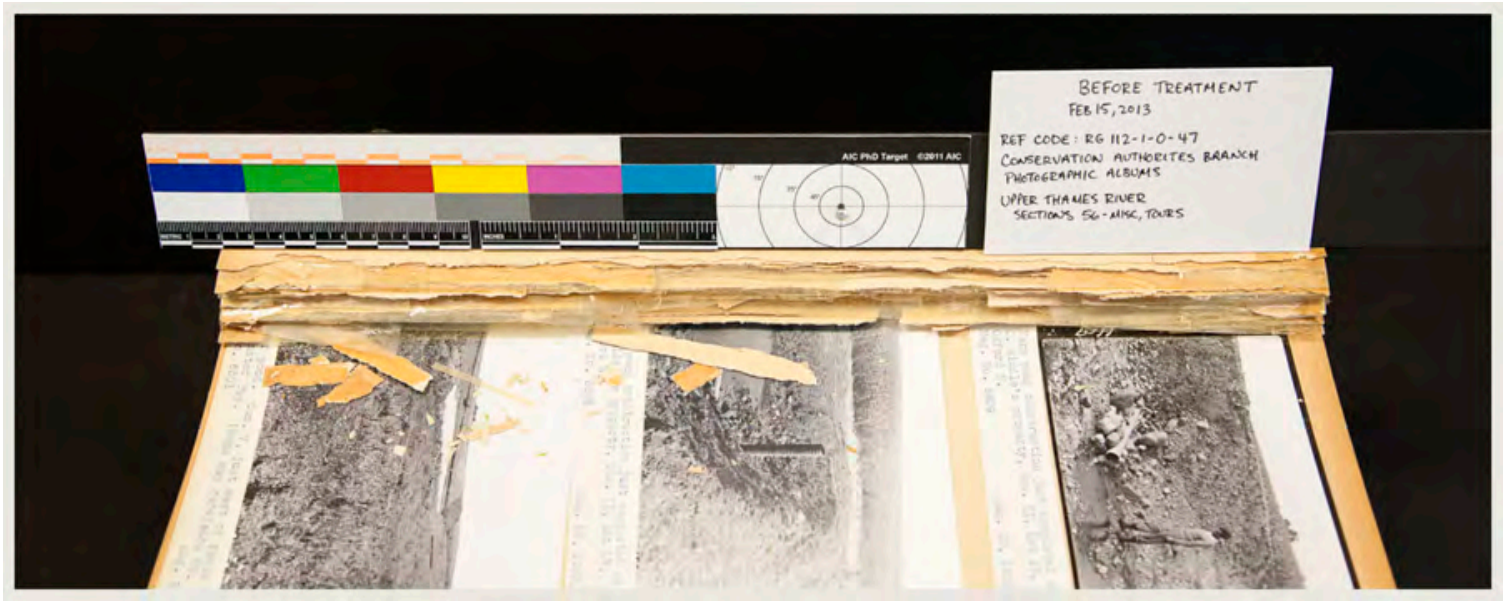

Figure 18: Condition photo of RG 1-112-1-0-47.

\subsection{Preservation options and analysis}

Preservation options considered for this project included four main treatments: reformatting, encapsulation, lining or backing, and facsimile. Preservation options were evaluated based on several factors including accessibility, impact on future researchers, creator intent, available resources, financial costs, material culture, archival appraisal, and consistency with Archives of Ontario policies and procedures. 


\subsubsection{Reformatting}

Reformatting is the creation of a surrogate copy in a different format or medium. The emphasis on reformatting is to preserve the informational content of the record. Since the physical format of the object is modified, artifactual value is often sacrificed. Examples include microfilm or microfiche, photocopies, and digital files (digitization). For the purpose of this project reformatting in the form of digitization was researched.

Digitization is the conversion of physical or analog information into a representative digital form (expressed as a numerical description). Information can include a variety of source materials including textual based records (books, letters), graphic materials (photographs), moving images, sound, or three-dimensional objects. Digitization is often used to facilitate wider access to collections materials via online dissemination, but can also be used as a preservation tool to limit direct physical contact with fragile materials by providing users with a digital surrogate. Digitization is accomplished through the use of a digital capture device, generally in the form of a scanner or digital camera. Options include flatbed scanners, overhead scanners, sheetfeed scanners, drum scanners, microfilm scanners, slide scanners, and digital cameras. Digitization includes not only the conversion of information to ones and zeros, but also the application of appropriate metadata, storage and maintenance of data including backups and migration, and other technical concerns.

\subsubsection{Encapsulation}

Encapsulation is the placement of an object between two layers of transparent polyester film such as Mylar® D, Hostaphan ${ }^{\circledR} 43 \mathrm{SM}$, or Melinex ${ }^{\circledR} 516$, and then sealed on all four sides. Additional variations such as the L-seal in which only two sides are 
sealed, sealing only three sides, or leaving open gaps in the corners can also be used depending on the object encapsulated. Sealing methods include ultrasonic welder, thermal, or double sided tape $\left(\mathrm{S}_{\operatorname{cotch}}{ }^{\circledR} 3 \mathrm{M}^{\mathrm{TM}} 415\right)$. Encapsulation affords structural support to documents, and allows for viewing or handling while limiting direct physical contact with the object itself.

\subsubsection{Lining or backing}

Lining or backing is the process of adhering a secondary support to the primary support of an object. Lining can serve several functions: to consolidate, strengthen, support, provide an alkaline buffer, and facilitate handling to name a few. Secondary supports used in lining often include Japanese paper, western papers or fabrics. Lining involves the use of adhesives to attach the secondary support directly to the entire surface of the primary support. An alternative method, called strip lining, applies a partial lining to only the outer edges of an object when full lining is unnecessary.

\subsubsection{Facsimile}

A facsimile is a reproduction designed to closely resemble the original of an object. Facsimiles attempt to mimic and convey the artifactual value of an object, along with the informational content. Construction of a facsimile would entail removing the photographs from the original album pages and remounting them to new, acid-free album pages of the same size and colour.

\subsubsection{Analysis of preservation options}

As previously noted, general preservation recommendations exist for albums. The complicating factor with the CAB photograph albums is one often encountered by 
archives and other institutions that manage large collections of material, one of volume and resources. The scale of the CAB photograph albums, 60 albums and approximately 47,000 photographs (see Figure 19), presents the major challenge. What, where, and how

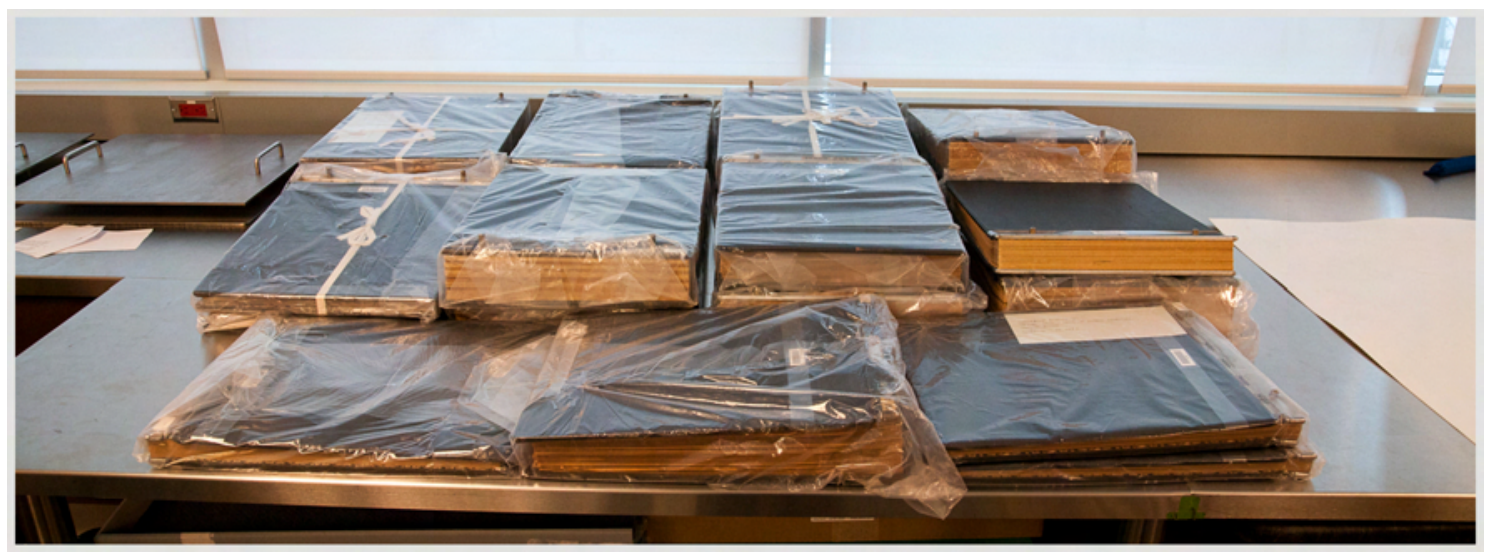

Figure 19: Illustration showing the size and number of albums. This photograph shows about one-third of the $\mathrm{CAB}$ albums.

does the institution make the compromises necessary to properly preserve materials while accounting for constraints in available expertise, resources, funding, and institutional needs? For the CAB photograph album project, it was imperative that the working method primarily be cost effective and efficient. Second, since this thesis project only proposes the treatment of one of the sixty albums, the process had to be replicable by others; and lastly, it was important for it to be relatively straightforward and uncomplicated to complete. While the AO possess very well trained and knowledgeable conservators, conservation staff is frequently occupied completing customer service orders, limiting their ability to assist with the project. Therefore, the desire was for a process that could be executed by interns or staff archivists.

Reformatting is a common preservation method for fragile documents, used widely in the preservation of acidic books, periodicals, and other textual based records. 
Microforms such as microfilm and microfiche are likely a familiar format for most who have spent any time in an archive or library. While the use of microfilm and microfiche has not disappeared completely, the advent of digital imaging technologies has led to digitization becoming a popular medium for reformatting projects, and because of its many benefits including facilitating access, and preservation of the original object through the use of a digital surrogate, digitization was initially considered for the CAB photograph albums.

The $\mathrm{AO}$ as an institution remains a relatively traditional archive in regard to access of its collection, and user desires and expectations. The majority of researchers utilizing AO records still prefer to access physical objects and original records over digital surrogates. ${ }^{4}$ The importance of preserving the CAB albums as material culture was also a concern. While currently functioning as a visual index for the negatives, there is evidence
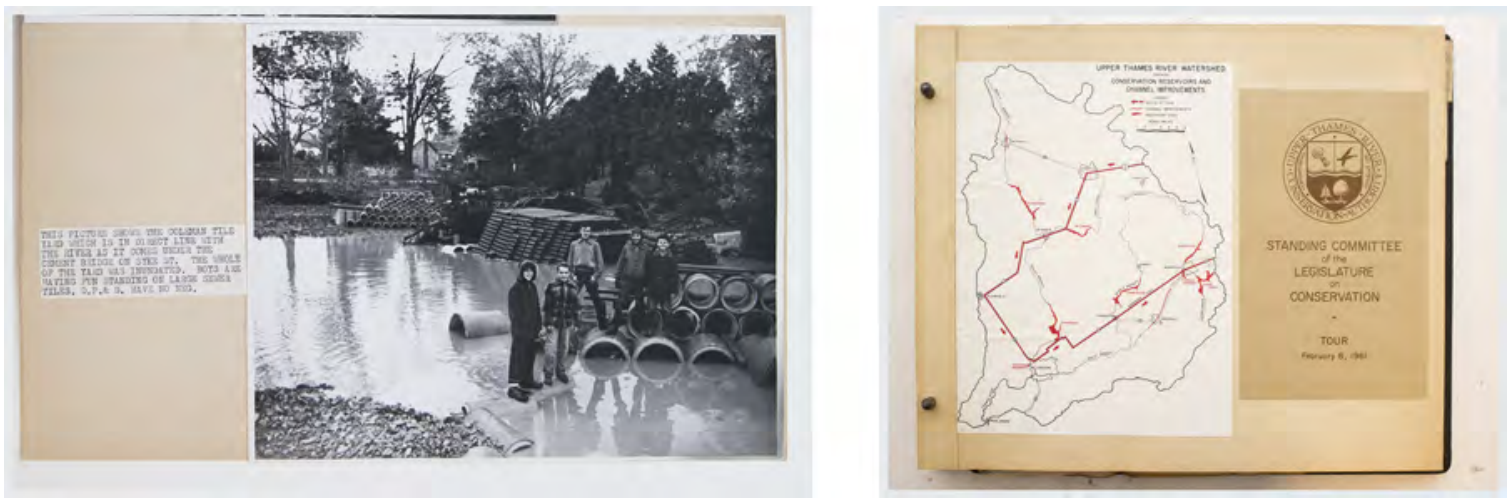

Figures 20 and 21 (L to R): Example of photograph with no negative. Sample of scrapbook elements found within album pages.

to suggest that the albums were not specifically created to serve as a visual index alone. Many albums for example contain photographs with no corresponding negative, press photographs acquired from local newspapers, and photographs for which copyright for the image does not belong to the CAB (see Figures 20 and 21 above). Other albums

${ }^{4}$ Dee Psaila, Senior Conservator, Archives of Ontario, personal communication. 
contain photomechanical reprints of photographs used in publications, and several are scrapbook in nature, containing $\mathrm{CAB}$ publications and documents. In addition, the AO has no formal digitization policy or plan for its collection. ${ }^{5}$ Presently, the only records that are regularly digitized are those pertaining to vital statistics (birth, marriage, and death), which are widely used by genealogists. Digitization of other information generally occurs as records are retrieved for customer service requests, or on an as-needed basis. The longterm costs associated with digital preservation were also a limiting factor for this project. Fees for server storage required for the digitization of the CAB albums would be approximately $\$ 7,200$ on a recurring annual basis. ${ }^{6}$ This figure only accounts for a single image of each album page; additional detail images of individual photographs would raise the total cost of server storage significantly. Digitization also does nothing to preserve the albums, which will continue to deteriorate without intervention. The AO is also currently looking to be certified as a Trusted Digital Repository ${ }^{7}$. One of the requirements of Trusted Digital Repositories is replication of data, having multiple copies of data stored in separate geographic locations, which would compound the annual costs of storage by a factor of at least two or three depending on the replication plan. Digitization was therefore not recommended for the $\mathrm{CAB}$ photographs at this time, largely due to associated costs, and the current character of the Archives of Ontario as an institution.

Lining, as described above, includes adhering a secondary support to the primary

\footnotetext{
${ }^{5}$ Lare Chapman, Digital Outreach Coordinator, Archives of Ontario, personal communication.

${ }^{6}$ Based on an average of $8 \mathrm{~GB}$ of storage space per album or approximately $480 \mathrm{~GB}$ for all sixty albums, and the AO current server costs of $\$ 1.25 / \mathrm{GB} / \mathrm{month}$.

${ }^{7}$ For additional information on Trusted Digital Repositories see: Research Libraries Group. "Trusted Digital Repositories: Attributes and Responsibilities." Accessed February 13, 2013.

http://www.oclc.org/content/dam/research/activities/trustedrep/repositories.pdf?urlm $=161690$
} 
support of an object, and was considered because it provided multiple benefits to the album pages. The addition of the secondary support would provide structural integrity to the pages, facilitate handling, and could be used to consolidate broken pages. Despite these advantages, lining also had several drawbacks. Because of their strength, flexibility, and weight, Japanese papers are often the material of choice for lining applications. A large variety of Japanese papers are available - handmade, machine made, different grades, fiber types, and processing methods - making navigating paper selection alone a formidable task. Good quality Japanese papers suitable for lining are also expensive. The dimensions of the album pages and total number of pages needing to be lined would have resulted in substantial material costs. Lining also requires a great deal of specialized knowledge, skills, and the evaluation of several factors. Determining the support material; choosing an appropriate adhesive - natural or synthetic, water or solvent activated; and variations in the actual lining method - wet, dry paste, double, and non-aqueous; are just a few of the considerations when completing a lining project. Additional aspects such as paper grain, expansion and contraction ratios, reversibility, and aesthetic changes also need to be appraised. While conservation staff possessed the expertise necessary to advise and undertake a lining project, and a test album could have been completed, replication of the treatment by interns or archival staff was uncertain. Time resources required for a lining project of this scale would also have been substantial. Based on ease of completion, costs, and time, lining was not considered a preferred option.

Since the main concern with the albums is deterioration of the acidic pages, facsimile reconstruction of the albums using the original photographs and higher quality acid-free materials was also considered as a treatment option. The post-binding structure of the album would have easily allowed for the old pages to be removed, replaced and the 
covers reused. However, other factors limited the use of facsimile for this project. The removal of the approximately 46,000 photographs from the sixty albums would have been incredibly time consuming. Photographs were mounted using a combination of dry mount tissue and an unidentified adhesive. While the photographs mounted using dry mount tissue may have been easily removed, testing would need to be performed on the unknown adhesive to first accurately indentify it and its properties, and then subsequent testing for adhesive removal would have needed to be conducted. Additionally, photographs were largely accompanied by type written labels requiring removal or duplication, both labor intensive as well. Facsimile may have been a reasonable approach had there only been one or two albums, but given the scope of the CAB albums, facsimile was beyond the needs and standard protocol of the AO. Facsimile proved to be too time consuming, resource intensive, expensive, and because it involves direct physical mediation of the object, is largely outside the scope of the Photographic Preservation and Collections Management program.

In comparison to the previous three options, encapsulation appeared to be a favorable solution. Encapsulation would protect album pages and prevent additional damage from tearing, breaking, or chipping; the static charge created between the two sheets of polyester could be used to consolidate broken pages without the use of adhesive; handling would be facilitated as there would no longer be direct contact with the album pages; the process is easy and could be completed by interns or archival staff; and treatment would require no physical alteration of the original object and is completely reversible. The $\mathrm{AO}$ was also already in possession of an ultrasonic welder to perform the encapsulation. While encapsulation can be completed using double stick tape, use of the welder provided additional benefits such as increased efficiency, lower cost (not including 
the cost of the welder), and ease of operation by interns or archival staff with minimal training.

Even with encapsulation's many benefits however, there were concerns that needed to be addressed. A minor concern was the additional volume that would result from the polyester sheets. Polyester sheeting is available in many thicknesses (gauge) ranging from 0.0005 inches -0.010 inches and often referred to in "mils" where one mil is equal to 0.001 inches. Current best practices, and consultation with Preservation Services staff suggested 4-mil or 0.004-inch polyester sheeting as an appropriate choice for the $\mathrm{CAB}$ photograph albums. This gauge would minimize volume to the extent practicable, but still provide sufficient support and protection of the pages.

The chief trepidation with encapsulation however was the trapping of acidic materials within the packet. Previous studies have suggested that encapsulation of acidic materials may accelerate deterioration, and most sources recommend the deacidification of material prior to encapsulation. ${ }^{8}$ While deacidification ${ }^{9}$ of the album pages would have been the best option, once again the scale of project made both aqueous and nonaqueous methods of deacidification impractical. Aqueous methods would have required testing for solubility of inks and other label inscriptions, and testing the paper and

\footnotetext{
${ }^{8}$ For more information see: Library of Congress, Chandru Shahani, "Accelerated Aging of Paper: Can It Really Foretell the Permanence of Paper," from proceedings from the ASTM/ISR Workshop on the Effects of Aging on Printing and Writing Papers, Philadelphia, PA, July 1994; Ellen McCrady, "Accelerated Aging and the Effects of Enclosures," Abbey Newsletter, Volume 8, Number 2 (April 1984); and John B.G.A. Havermans, "Ageing behaviour of encapsulated paper," Restaurator: International journal for the preservation of library and archival material, Volume 20, Number 2 (1999): 108-115. 9 Neutralization involves applying an alkaline agent to react with acids, resulting in formation of a salt. Alkalization is similar to neutralization but is designed to leave an alkaline reserve, also known as buffering. Deacidification is a general term that refers to the removal of acids, generally through washing of the material. It includes concepts of both neutralization and alkalization. Although less precise, the term deacidification has been used here for simplicity.
} 
photographs to withstand aqueous treatment. Other obstacles included the time and physical space required to wash and dry the album pages. Aqueous deacidification is generally a procedure completed by trained conservators, therefore the ability of interns or archival staff to perform the treatment would be highly limited. Non-aqueous methods were generally cost prohibitive but would also have required initial testing, and results tend to vary depending on the mode and efficacy of application.

To help mitigate concerns with acidity, a proposal to place a piece of buffered folder stock inside the encapsulated package was recommended. The buffered folder stock would serve two functions. First it would provide an alkaline layer to help absorb some of the acidic byproducts, and second it would provide structural support for heavily damaged pages, or pages needing consolidation. This would also allow non-specialized staff to perform the treatment quickly and safely.

Encapsulation alone however did not seem an appropriate treatment for all of the pages. Inclusion of the buffered folder stock relieved some of the concern over the acidic nature of the album pages, but the folder stock also further increased the bulk of the album in addition to the two sheets of polyester sheeting. While some increase was unavoidable, minimizing was necessary to prevent already large volumes from becoming too unwieldy. Encapsulation is best suited for flat objects, meaning that album pages that were cockled could not be encapsulated either. Humidification and flattening of cockled pages was discussed with conservation staff, but was considered impractical. Many pages showed some forms of paper deterioration, but were largely intact as well. Given the uncertainty of encapsulation and accelerated deterioration, if pages did not warrant encapsulation it was felt best to develop an alternative preservation method.

Initial alternatives included the use of paper corners, however since many of the 
pages were chipped or otherwise damaged along the edges and corners, this proved less than ideal. Cockled pages would also be difficult to mount using corners. Ultimately a modified backing procedure was suggested that consisted of hinging an album page to a buffered folder stock support, rather than completely adhering the support to the page as in a traditional lining procedure. This would provide many of the benefits of backing such as physical support and the addition of a buffering layer; but would not require extensive mediation of the object since it would only require two small hinges to be attached to the album page. It would also be more cost effective - buffered folder stock is less expensive than Japanese tissue, less labour - hinging versus full lining, and facilitate access since the support board rather than the page could be used to handle the object. Hinging would also be a suitable alternative for cockled pages that could not be encapsulated, and for pages showing minor deterioration but that were largely intact. A hinge consisting of small strips of Japanese tissue and a 5\% solution of methyl cellulose was proposed. This combination would be fully reversible, strong enough to hinge the material properly, but should fail before damage to the object occurs. The modified hinging method would also minimize bulk since the two sheets of polyester sheeting would not be necessary.

The final aspect for evaluation was reassembly of the album. An advantage of the post-binding used for the $\mathrm{CAB}$ albums is it would have accommodated the increase in volume from the added polyester sheeting and folder stock. Both encapsulated pages and hinged pages could have been created with holes punched either in the support board or in an attached tab to fit the post-binding system. Upon further evaluation it was noted that the post-binding structure itself was limiting the ability to interact with the albums. While lying flat on its back cover, the front cover and subsequent pages are limited by the post-binding mechanism (see Figure 22), and pages are unable to lie flat, or turn in a 

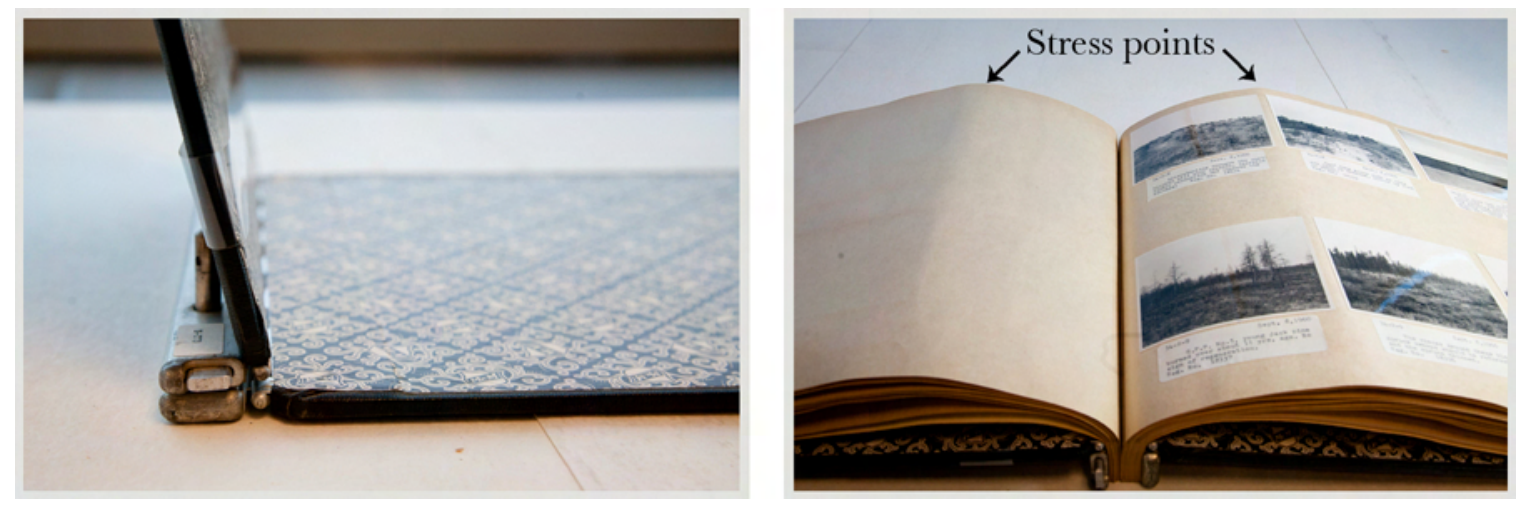

Figures 22 and 23: Illustrations showing the limiting nature of the post-binding structure and stress points between mounted photographs.

manageable fashion as in reading a book, and instead are forced to bend on top of each other. This problem is aggravated as the albums increase in size. The result is a large deal of stress on pages at the gutter, the point where most page breaks occurred. The placement of photographs combined with the restrictive binding was also the cause of stress, and several instances of pages breaking between photographs were observed. Smaller albums can be laid flat by opening both the front and back covers and positioning the spine downward, but this configuration still produces a great deal of stress on pages, particularly between mounted photographs (see Figure 23), and cannot be done with larger albums. A different way of handling the pages was necessary. Originally the proposal was to remove the pages from the post-binding for viewing and then replace them after each use. While feasible, this option would likely result in a great deal of strain on the pages and result in inadvertent damage. The option of removing the pages from their original binding and housing them in custom-made boxes was proposed. While removing the front and back covers to the albums would alter the original object, after consultation with Preservation Services staff and senior archivists, the consensus was that 
removal of the covers would not negatively alter the album's ability to function as an archival record, and that the damage caused by the binding was of more concern than the loss of artifactual value associated with the covers. To account for the loss, prior to treatment each album would be documented to represent its original construction, and a note regarding its treatment and the removal of the binding would be placed with each album.

\subsection{Business case}

Proposed preservation treatment options for the CAB photograph albums were submitted to the Archives of Ontario (AO) in the form of a business case. The business case is a formal written process utilized by the $\mathrm{AO}$ for internal decision-making, and approval of projects and initiatives. Information for the business case includes project background, current project status, analysis of appropriate options, and a recommended course of action. Use of the business case model for this thesis was intended to model the relationship and services of an independent contractor. While research, analysis, and recommendation of treatment options was my sole responsibility, the $\mathrm{AO}$ would be provided final discretion to approve the option that best fit their current needs and available resources. A copy of the business case model is located in Appendix D and includes recommended treatment options and estimated project costs. 


\section{Treatment}

\subsection{Treatment description}

The established working method chosen for preservation consists of a multi-phase approach utilizing encapsulation or hinging to a backing support, along with re-housing of album pages in custom-made boxes constructed of acid-free corrugated board, and lined with sheets of MicroChamber interleaving paper. ${ }^{10}$ Encapsulation was chosen for pages that showed a high degree of deterioration, were broken in multiple pieces and in need of consolidation, or were extremely brittle. Encapsulated pages and hinged pages were designed to have the same overall size (15 inches by 18 inches) after treatment to facilitate storage, and since they would no longer be bound, all pages were labeled with identification information and page number to retain original order. Additionally, hinging was used for pages that were either unsuitable for encapsulation (such as cockled pages), intact pages showing little wear, and pages in stable condition. Decisions on whether to encapsulate or hinge was made based on criteria located in Appendix E.

Encapsulation was accomplished using the following method. Two sheets of 15inch by 18-inch polyester film were prepared and welded first along a long edge, resulting in a folder shape. A sheet of 14.5 inch x 17.5 inch, 10 point or 0.010 inch buffered folder stock was labeled in pencil with identification information and page number in the lower right recto corner. The album page was placed on top of the support board, and both were placed inside the polyester folder. The remaining three edges were then welded,

${ }^{10}$ MicroChamber paper is a buffered $100 \%$ cotton paper manufactured by Conservation Resources. It contains their proprietary SPZ zeolite, designed to create molecular traps that aid in neutralizing acids, pollutants, and other deterioration by-products. For more information see: "MicroChamber Interleaving Paper," accessed August 7, 2013, http://www.conservationresources.com/Main/section_15/section 15_03.htm. 
starting first with a short edge, then the long edge, and lastly the final short edge.

Encapsulation was facilitated by the use of magnetic sheets to hold the encapsulated packet securely to the base of the welder. This prevented the packet from moving, but also helped remove air from the packet, ensuring a clean and precise weld. Guide marks, made from green masking tape, were placed on the welder and used to ensure consistency with weld widths, since the final encapsulated package could not be trimmed and needed to be a consistent size when finished.
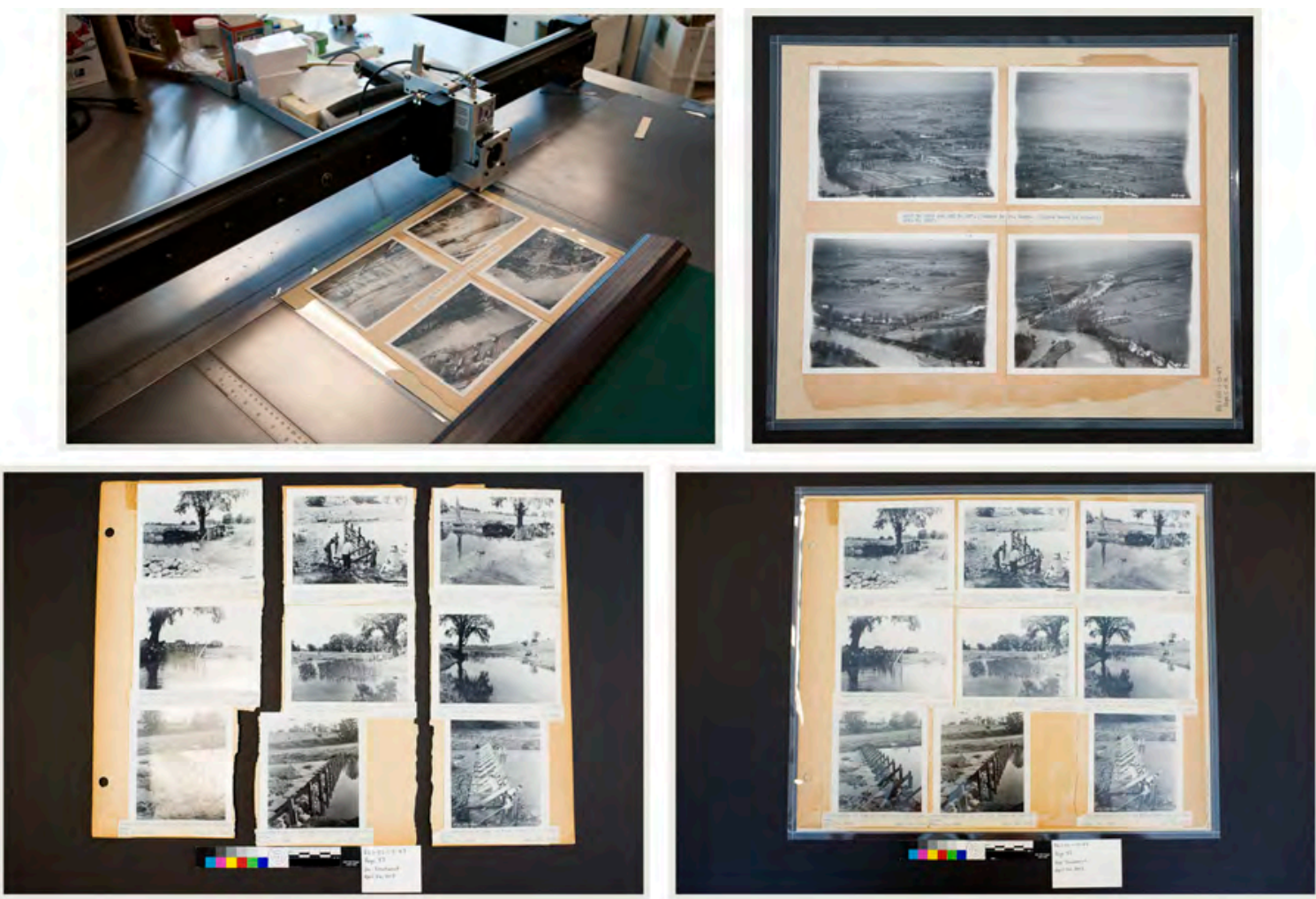

Figures 24-27 (clockwise L to R): Illustration showing the ultrasonic welder used for encapsulation, the magnetic sheet (green) can be seen in the lower right corner. Example of an encapsulated page. Page 37 after encapsulation and re-consolidation. Page 37 prior to encapsulation and in multiple pieces.

Hinging was performed using the following method. Small strips of Japanese Tengujo tissue approximately $1.75 \mathrm{~cm}$ x $3.5 \mathrm{~cm}$ were torn to size, and a $5 \%$ methyl 
cellulose mixture prepared. ${ }^{11} \mathrm{~A}$ sheet of 10 point buffered folder stock cut to an overall size of 15-inches by 18-inches was labeled in pencil with identification information and page number in the lower right recto corner. An album page was lined up with the support board and weighted with fabric-covered weights to prevent movement. A self-
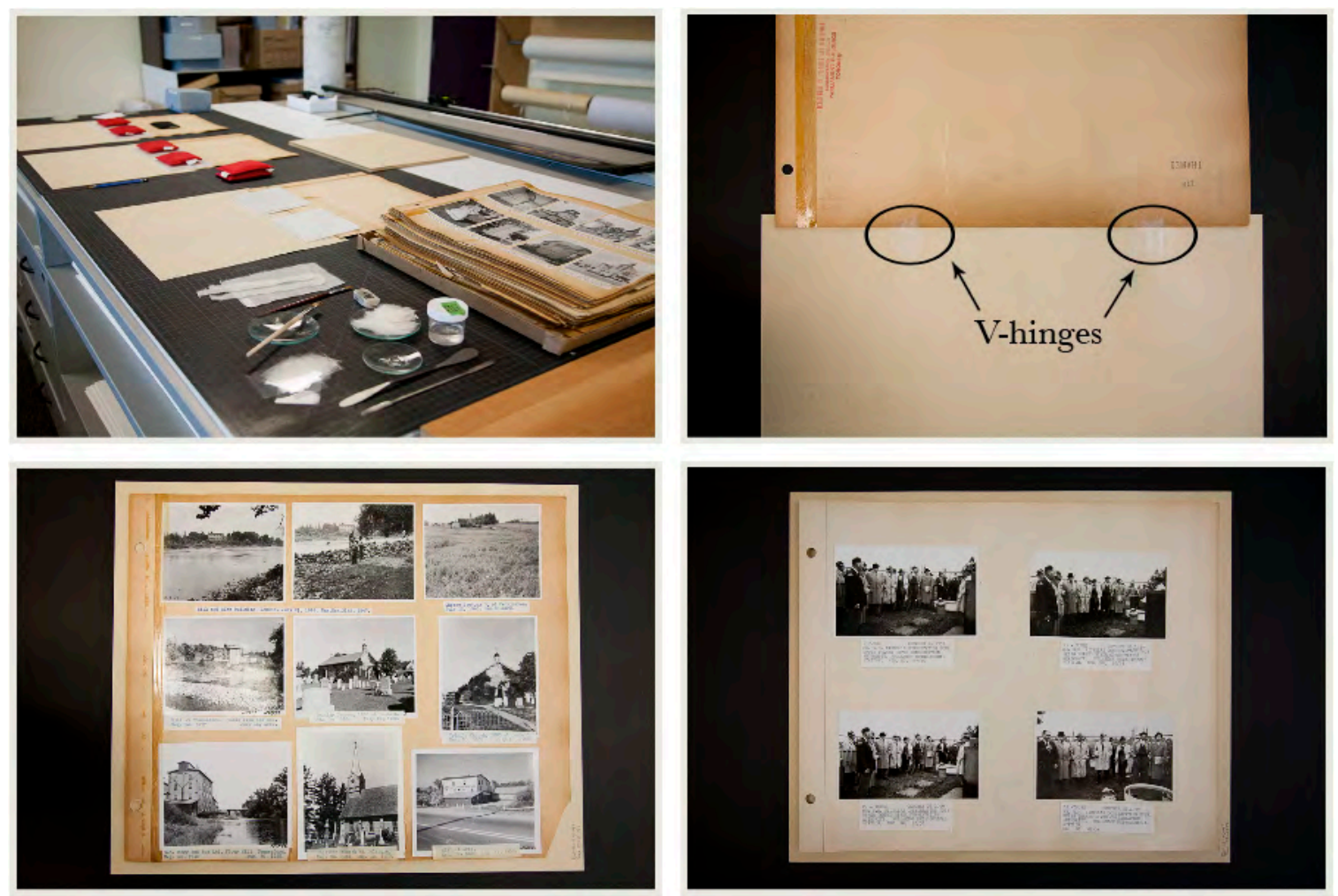

Figures 28-31 (clockwise L to R): Workstation set up for hinging pages. Example of V-hinge used for hinging pages. Two examples of hinged pages.

healing mat cutter with half inch gridlines was used to facilitate placement of the album pages on the support board to ensure consistency without the need for constant measuring. A strip of Japanese tissue was pasted out onto a piece of glass with the methyl cellulose, removed from the glass, and brushed out on to the album page and support board to create a $\mathrm{V}$ hinge by adhering approximately one-third of the hinge to the album page, and the remainder to the support board. The album page is then folded over so the

${ }^{11}$ See Appendix F for information on preparing methyl cellulose. 
hinge creates a "V" shape. The pasted-out hinge was dried utilizing a blotter stack consisting of alternate layers of spun polyester (Hollytex) to prevent sticking, and a 30point $(0.030$ inch) blotter board to absorb moisture. The stack was then weighted with plexiglass and a fabric-covered weight for approximately 10 minutes, or until the adhesive was no longer tacky. Ideally, blotter stacks should be allowed to dry under weight overnight, however due to workstation constraints this was not feasible. Instead, small pieces of polyester film were placed over the hinges between the album page and support board to prevent sticking, and the treated pages stacked on each other to dry. The pieces of polyester film were removed from the album pages the following day.

The final step for treatment was the construction of custom-made two-piece drop front boxes to house the album. Boxes were constructed from B flute corrugated board and Jade 403 adhesive. MicroChamber paper was used to line the lid and tray of the boxes as an extra measure of protection from potential deterioration by-products. Because of the added volume from the polyester sheets and folder stock, the album was split into two boxes for ease of handling. Enclosed with each box is a brief statement explaining that this album has undergone preservation treatment, and instructs the user on proper care and handling of the album. The first of two boxes also contains an additional note in regard to the first eleven pages of the album. During the pre-treatment condition report, these eleven pages were located at the beginning of the album. The pages had separated from the binding, and their original order could not be accurately determined. Rather than impose an artificial order on the pages by placing them within the album, the decision was made to label these pages A-K to distinguish them from the others, and keep them at the beginning of the album. The remaining album pages were numbered numerically, starting with number 1 . 

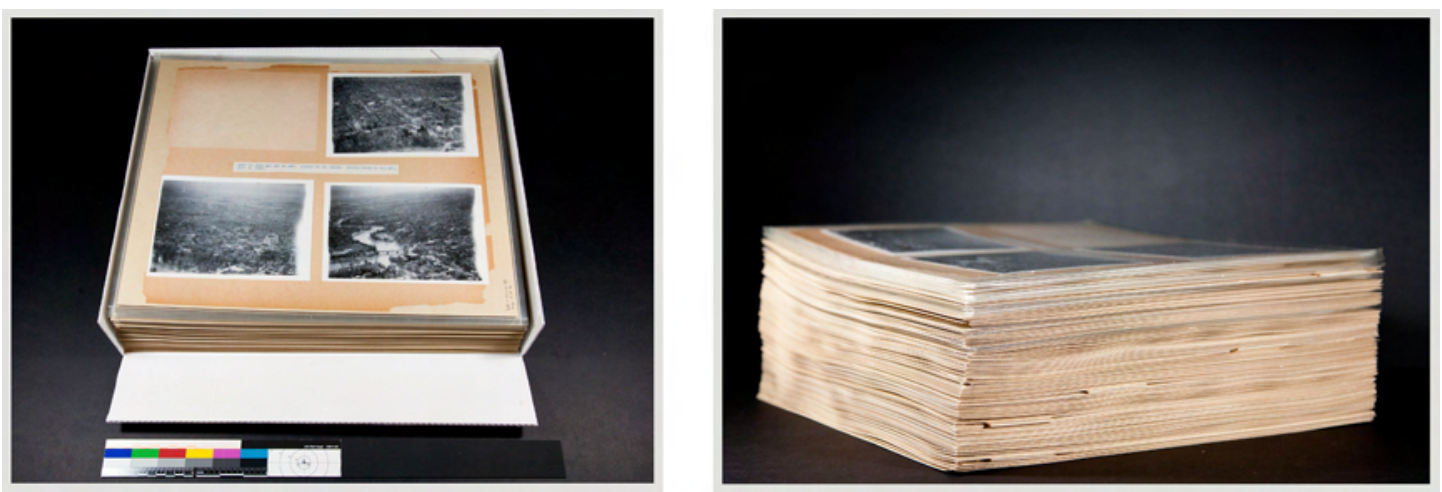

Figures 32 and 33 (L to R): Box 1 of completed RG 1-112-1-0-47, pages A-K are visible on top. RG 1-112-1-0-47 post-treatment.

\subsection{Treatment results}

Based on the results of the case study album, the proposed method of encapsulation and hinging appears to be a viable method for preservation of the remaining $\mathrm{CAB}$ photograph albums. The treated album is fully accessible, and potential damage from handling has been greatly minimized. Discussions with both Preservation Services staff and senior archivists at the AO have indicated a great amount of satisfaction with the end product. RG1-112-1-0-47 will be re-opened for public access, and initial plans are to have interns complete additional albums in subsequent years. Also of interest was the ratio of encapsulated pages to hinged pages being different than anticipated. RG 1-112-1-0-47 contains a total of 168 pages, with only 21 being encapsulated. This ratio will undoubtedly vary from album to album, but was still a bit unexpected. As hinging proved more versatile and efficient than initially anticipated, and due to the concern with encapsulation of acidic materials, the decision to err on the side of caution was exercised, and pages were generally encapsulated only if they were unsuitable for hinging (contradictory to the original proposal). Recent research released after completion of the case study album however, suggests that encapsulated materials do not age at an 
accelerated rate in comparison to un-encapsulated materials. ${ }^{12}$ Nonetheless, the inclusion of the buffered folder stock in the encapsulated pages remains prudent as a preservation measure, and still provides the benefit of physical support.

Treatment cost for preservation of the case study album was approximately \$83.16 (material costs, excluding labour). Rehousing of the album added an additional $\$ 40$ for two sheets of 48” x 96" B-flute corrugated board. Total treatment time to complete encapsulation and hinging of the case study album was estimated at approximately 30-35 hours. As with many projects, work times are generally slightly higher at the beginning as processes are refined and streamlined, and even with the case study album, work was completed much quicker toward the latter half of the album. Work on the album was also conducted sporadically, reducing efficiency. Preparation time was another factor. While the project benefitted from the purchase of polyester film precut to the requisite size, for economy, folder stock was purchased in large sheets, which required cutting to size, and strips of Japanese tissue used for the hinges needed to be hand torn from larger pieces.

12 See William Minter and John W. Baty, "The Role of Polyester Film Encapsulation With and Without Prior Deacidification - On Paper Degradation" (paper presented at the $41^{\text {st }}$ annual meeting for the American Institute for Conservation, Indianapolis, Indiana, May 29 - June 1, 2013). 


\section{Conclusion}

Preservation and access are key functions of all cultural institutions, and generally an integral part of their remit. Records have little significance if they are locked away or unusable because of physical condition. The importance of preserving the Conservation Authorities Branch photograph albums however, extends beyond simply meeting the mandate of the Archives of Ontario. From environmental historians tracking changes in land use patterns, to hydrologists looking for information on historic flood patterns (particularly relevant given the recent July 2013 flood event in the Greater Toronto Area), or for researchers interested in the formation and evolution of local conservation authorities, the $\mathrm{CAB}$ photograph albums contain a wealth of information in both the content of their images and as objects themselves. Preservation and subsequent reopening of the $\mathrm{CAB}$ albums not only fulfills the requirements of the $\mathrm{AO}$ as the cultural repository of Ontario's cultural heritage, it opens the path to gaining the knowledge contained within the records.

Additionally, the preservation of a large volume of objects is often an examined compromise between the very best options available and appropriate allocation of resources. For archives such as the $\mathrm{AO}$ and other institutions that are often dealing with high volume rather than singular high monetary value records, the balance between preservation and access can be difficult. Decisions are often collaborative, and require the assessment of many criteria. The need to preserve the records is paramount, followed by the mandate to make those records accessible. Available resources - financial and technical - along with considered thought regarding the nature and value of the records (archival, informational, artifactual), the needs and desires of researchers, and the policies 
and procedures of the institution are critical to any preservation project.

While based on resources available at the $\mathrm{AO}$, attempts have been made to either make this approach as simple and accessible to a variety of institutions as possible, or to provide additional alternatives and sources of information where applicable. Appendix G provides a list of materials, and suppliers researched for this project. This list is by no means exhaustive, but may be considered a departure point for those seeking additional information.

The method described above, while being specific to the CAB photograph albums, will be applicable to others, either in the approach taken or the rationale used for the decision making process. The incorporation of photographic preservation techniques and basic conservation principles provided an alternative means of addressing the treatment of the $\mathrm{CAB}$ albums, and was invaluable to the overall success of the project. This method presents practical and useable modes of evaluating and addressing the preservation and accessibility of material, which would be beneficial to smaller archives that lack conservation staff or the resources of a larger organization, but is also applicable to many institutions, large or small. As the funding outlook for cultural repositories such as archives, libraries, and museums is often unpredictable, creative and resourceful methods for preserving and maintaining access to institutional holdings will help meet the needs of their users. ${ }^{13}$

13 Public cultural institutions have in recent years been subject to considerable funding cuts in both Canada, and the United States. See for example: Association of Canadian Archivists. "National Archival Development Program - Call to Action." Accessed August 8, 2013. http://archivists.ca/content/national-archival-development-program-callaction; and American Institute for Conservation. "House of Representatives Appropriations Committee to Cut NEH Funding by 49\%." Accessed August 8, 2013. http://www.conservators-converse.org/2013/07/us-house-of-representativesappropriations-committee-to-cut-neh-funding-by-49/. 
Appendix A:

Results of 2013 Album Survey 


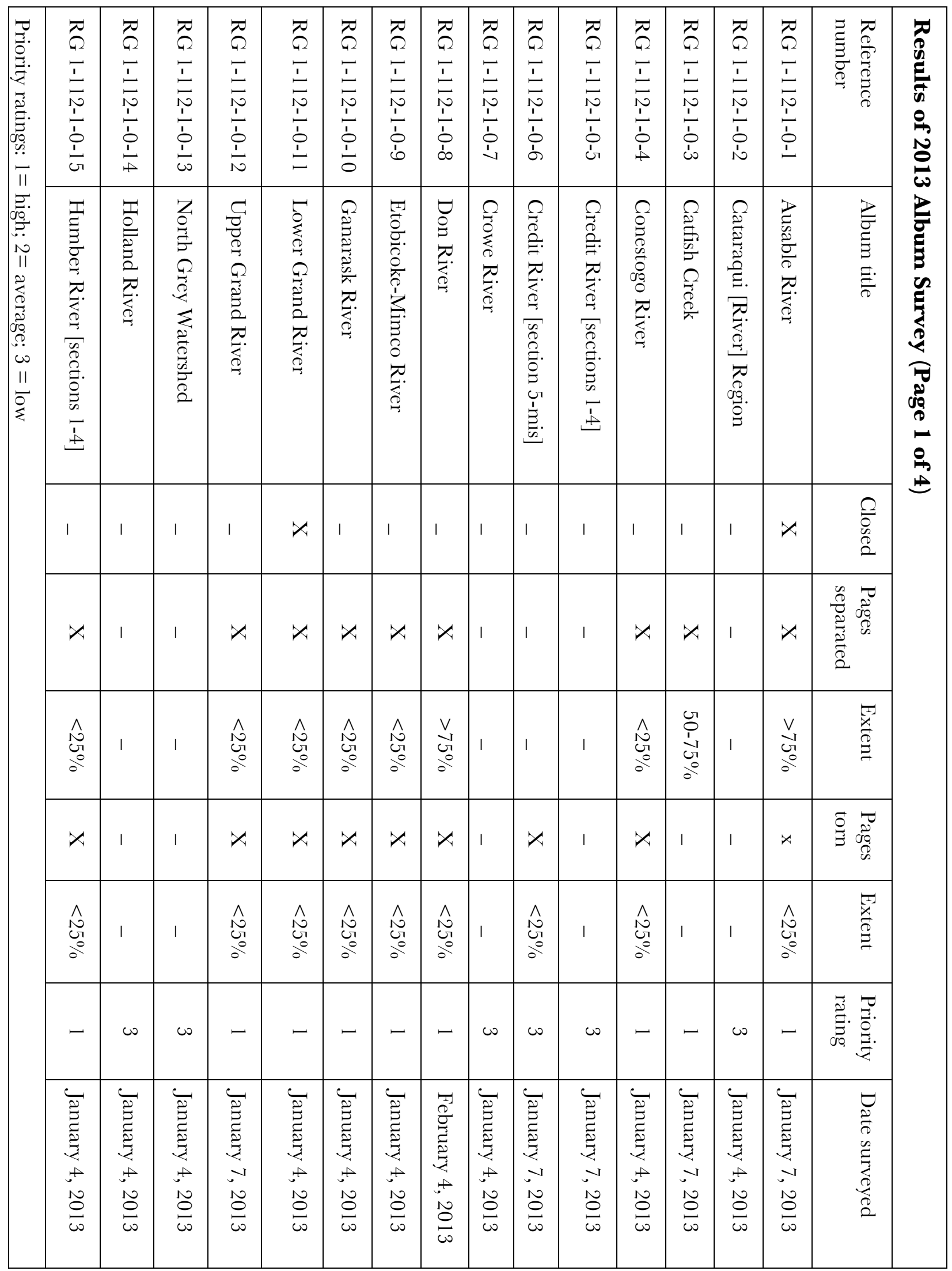




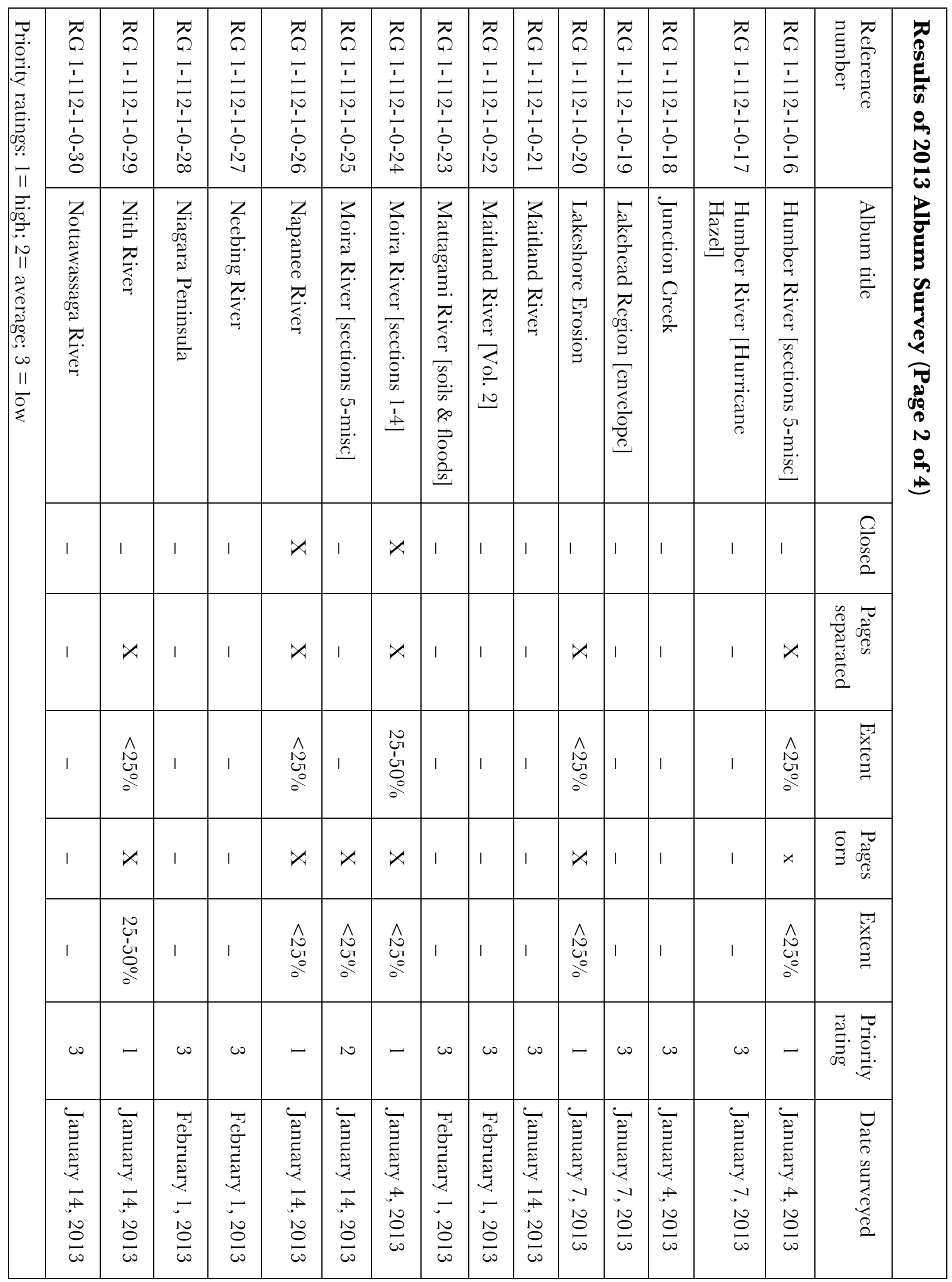




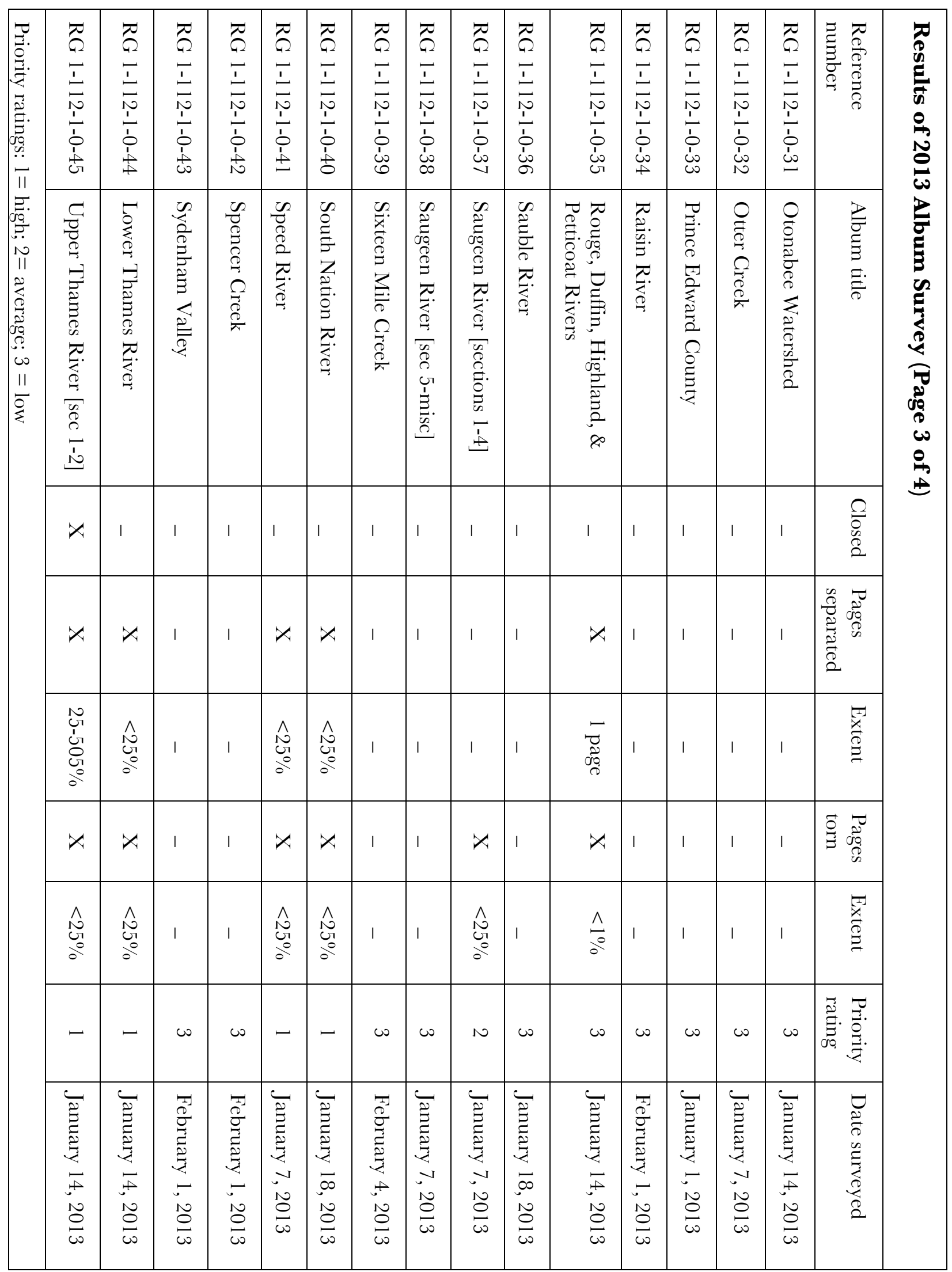




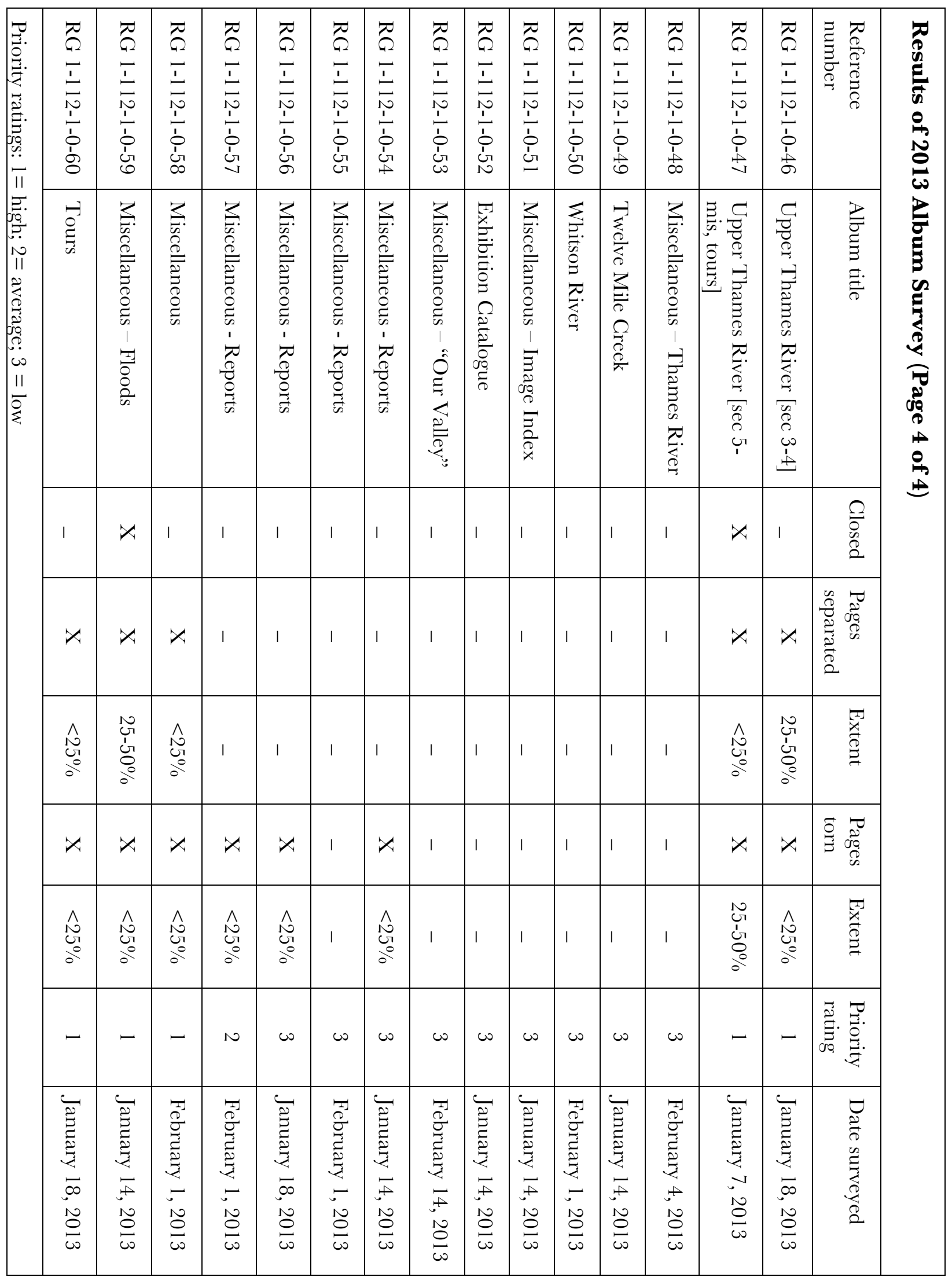


Appendix B:

Results of March 2000 Album Survey 


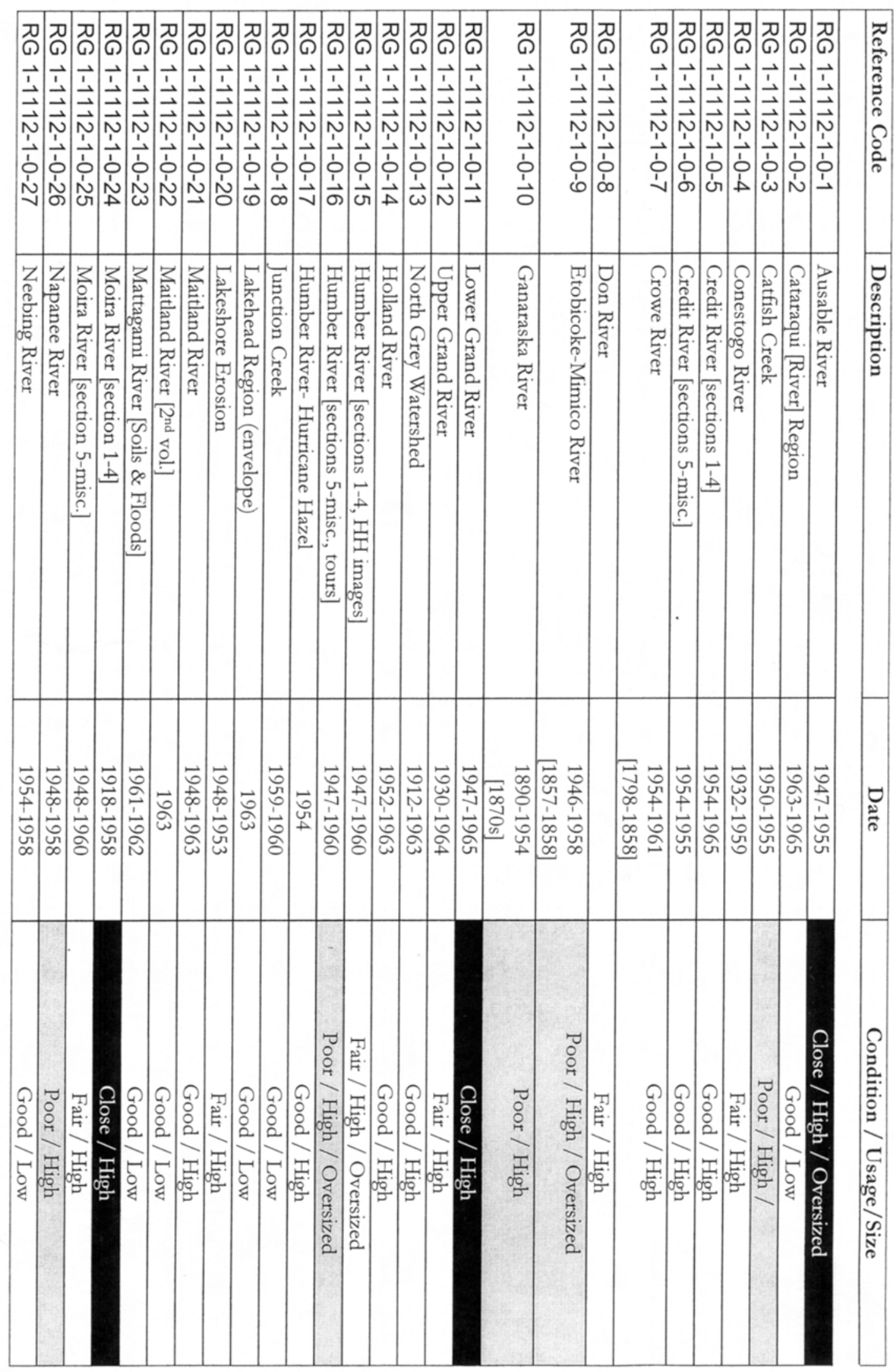



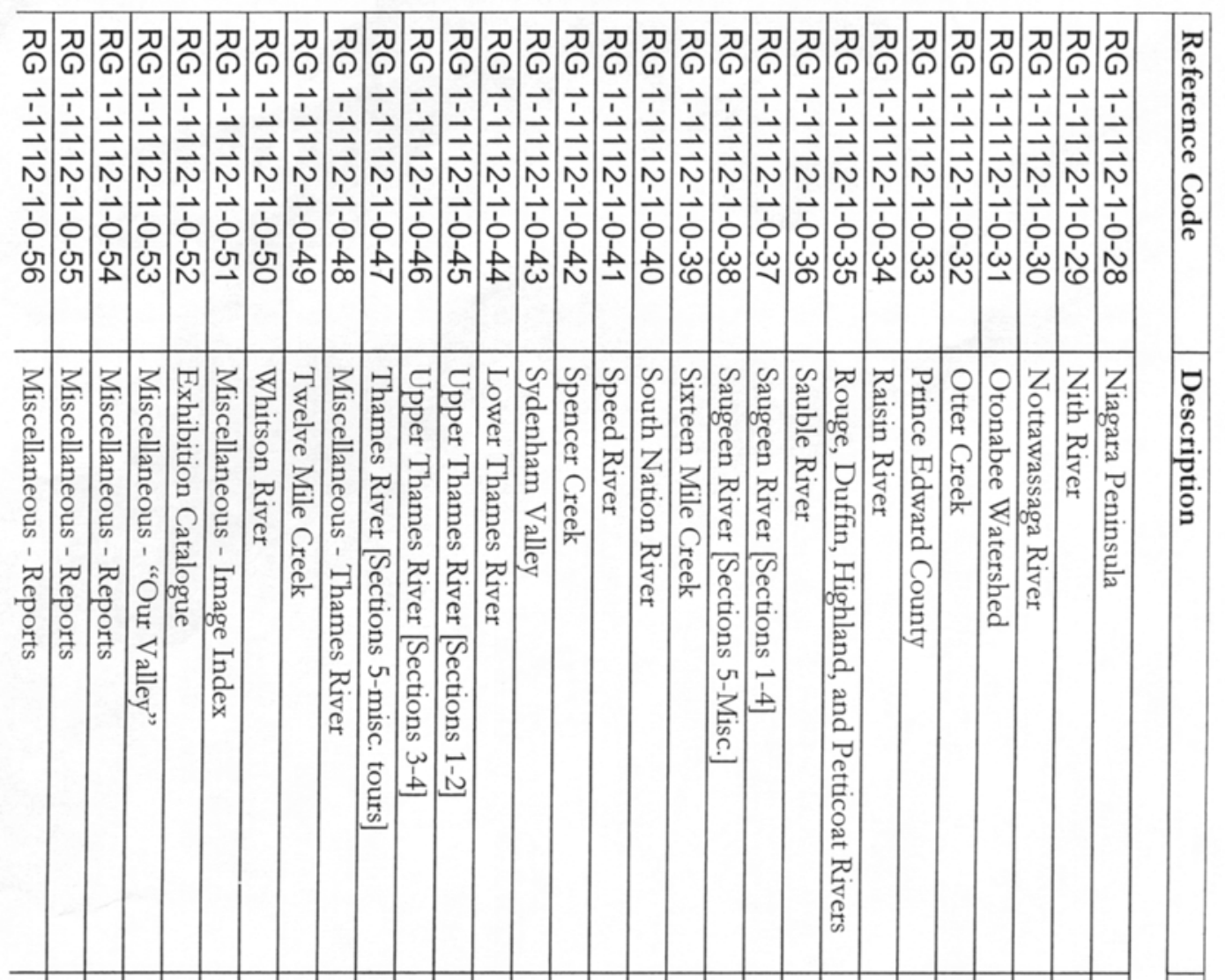

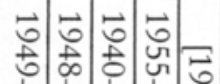
๖ेڤ

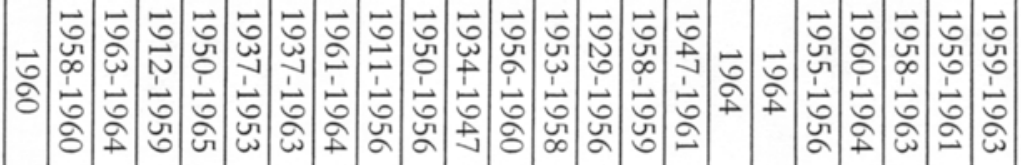

ซึ

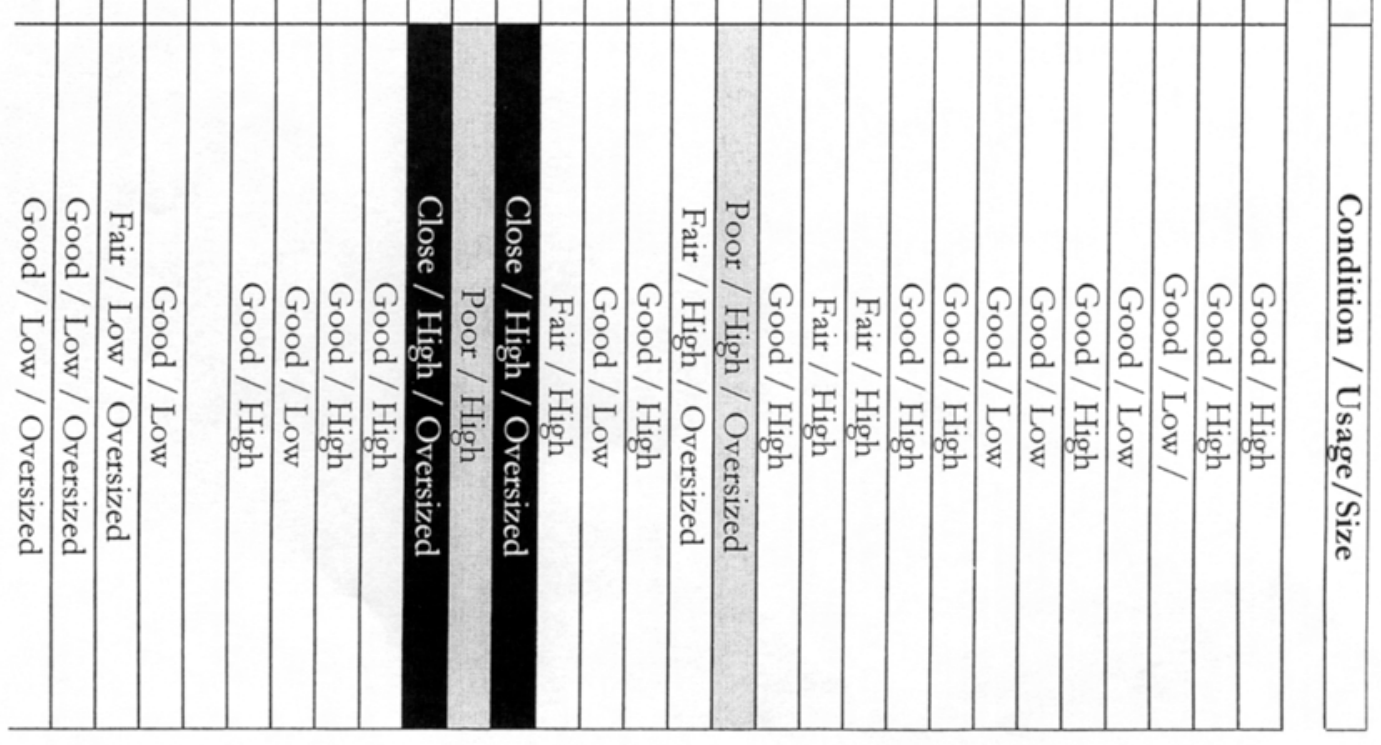




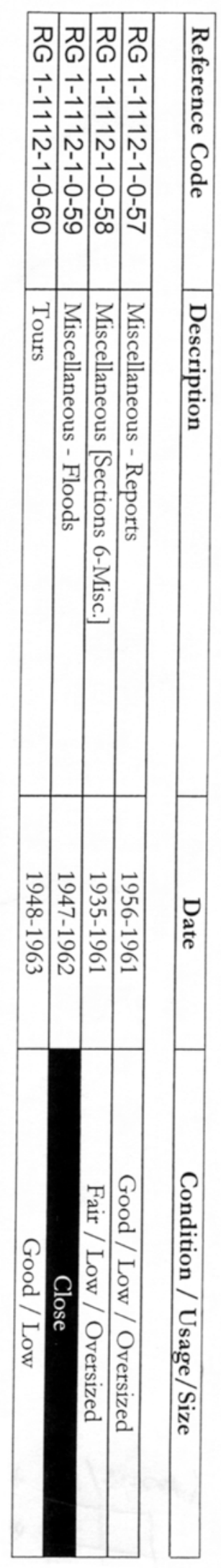




\section{Appendix C:}

Condition Report for RG 1-112-1-0-47 


\section{(8) Ontario}

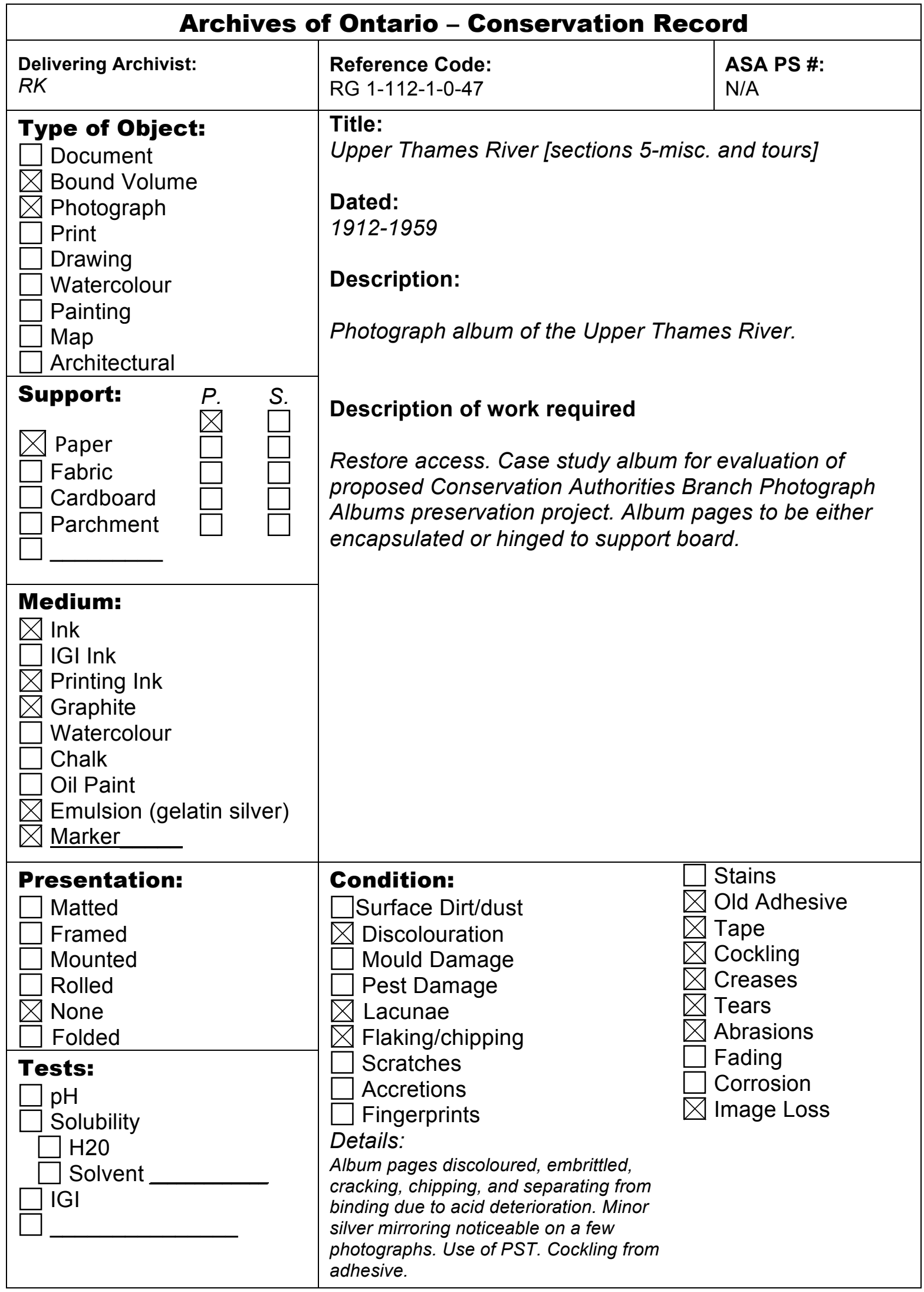




\begin{tabular}{|c|c|}
\hline $\begin{array}{l}\text { Date Received: } 2-15-2013 \\
\text { Estimated Time: N/A }\end{array}$ & $\begin{array}{l}\text { Date Completed: } 5-2-2013 \\
\text { Total Time: } 30-35 \text { hrs }\end{array}$ \\
\hline Proposed Treatment & Completed Treatment \\
\hline \multicolumn{2}{|l|}{$\square$ Testing } \\
\hline \multicolumn{2}{|l|}{$\square$ Dry Cleaning } \\
\hline \multicolumn{2}{|l|}{$\square$ Consolidation } \\
\hline \multicolumn{2}{|l|}{$\square$ Aqueous Cleaning } \\
\hline \multicolumn{2}{|l|}{$\square$ Solvent Cleaning: } \\
\hline \multicolumn{2}{|l|}{$\square$ Mould Remediation } \\
\hline \multicolumn{2}{|l|}{$\square$ De-acidification } \\
\hline \multicolumn{2}{|l|}{$\square$ Removal of Old Repairs/Tape } \\
\hline \multicolumn{2}{|l|}{$\square$ Repair } \\
\hline \multicolumn{2}{|l|}{$\square$ Infilling } \\
\hline$\bigotimes$ Lining & $\begin{array}{l}\text { Modified lining consisting of V-hinging album pages to } 10 \text { point } \\
\text { buffered folder stock using Japanese tissue and methyl } \\
\text { cellulose. }\end{array}$ \\
\hline \multicolumn{2}{|l|}{$\square$ Flattening } \\
\hline$\bigotimes$ Encapsulation & $\begin{array}{l}\text { Encapsulation in 4-mil polyester with addition of } 10 \text { point } \\
\text { buffered folder stock for support. }\end{array}$ \\
\hline$\triangle$ Re-housing & $\begin{array}{l}\text { Construction of two-part corrugated box, lined with } \\
\text { MicroChamber paper }\end{array}$ \\
\hline \multicolumn{2}{|l|}{$\square$ Matting/Framing } \\
\hline$\square$ Other: & \\
\hline
\end{tabular}

\section{Conservator: Ross Knapper}


Appendix D:

Business Case 


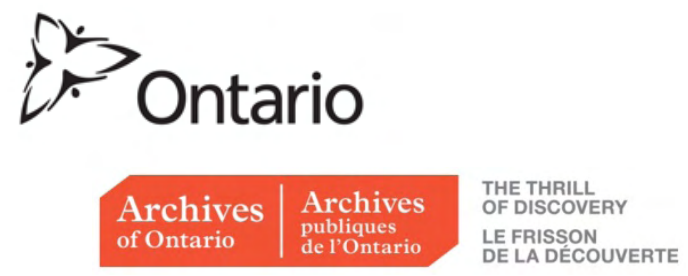

Business Case

\section{Conservation Authorities Branch Photograph Albums Preservation Treatment Proposal}




\section{Request}

Intern is seeking approval to perform preservation treatment on the Conservation Authorities Branch photograph albums (RG 1-112-1). Proposed treatment would restore public access to the albums, which have been placed on restricted access due to preservation concerns. Request is made in support of the student's applied research project for the Photographic Preservation and Collections Management Program, Ryerson University.

\section{Background}

The Conservation Authorities Branch (CAB) photograph albums were acquired by the Archives of Ontario between 1961 and 1978 through regularly scheduled transfers from the Ministry of Natural Resources, and include a total of 60 hard-covered post-binding albums. The albums, created by the CAB between 1947 and 1965, were assembled using commercially available products constructed of low-quality, acidic materials causing the pages of the album to become brittle, and resulting in pages breaking from the binding, crumbling of pages, and damage to the album pages and photographs.

In March 2000 the albums were examined by AO staff and ranked according to current condition (close, poor, fair, good), potential public use, and physical size (see Appendix A). Based on that examination six albums were identified as "close" and recommended for immediate closure, and seven albums as "poor" and recommended for monitoring and annual re-examination. Staff also recommended removing all albums from their post-bindings and rehousing in flat archival containers. As a result of this survey and the overall condition of the albums, the entire series became closed for public access.

The albums were re-examined by the intern in February of 2013 (Appendix B) and priority ranked according to current condition (poor, fair, stable). Based on the most recent survey, twenty-three albums were identified as "poor" and requiring immediate preservation treatment, three as "fair", requiring treatment as resources become available, and thirty-four as "stable".

\section{Current Project Status}

Since 2000, the CAB photograph albums have received little attention. Staff completed a typewritten transcript of the negative number and corresponding caption for one album in 2003, and Preservation Services staff examined a few of the albums in 2011, but no other work has been performed, and all 60 albums are still listed as closed for conservation reasons. Because they function as visual indexes to a corresponding subseries of negatives and photographs (RG 1-112-2), closure of the photograph albums has resulted in the closure of sub-series RG 1-112-2 as well. The results of the 2013 survey show that the conditions of the albums have depreciated since 2000 , with $22 \%$ requiring attention in 2000 to $38 \%$ requiring attention in 2013. The Ausable Creek album, RG 1-112-1-0-1 (Appendix C), has also deteriorated so extensively in that time frame, that the album is likely beyond preservation treatment, and will require full conservation treatment in order to make it accessible to the public.

The current condition of the majority of the CAB photograph albums is not suitable for general public use, and albums that are currently in "fair" to "stable" condition will continue to deteriorate due to the inherent vices of the album's materials and 
construction. Preservation treatment of the albums is required if the albums are to be reopened for public access. RG-1-112-1-0-1 should serve as an example to the eventual fate of all the $C A B$ photograph albums if preventative action is not taken in the near future.

\section{Option Analysis \\ Option 1 (recommended) - Physical preservation of objects}

Option 1 consists of a multi-step approach to physically preserve the albums, and includes encapsulation, support backing, and interleaving treatments. Encapsulation in 4-mil polyester sheeting (Mylar) would be utilized for albums in "poor" condition with pages that are broken, in multiple pieces, or evidence a high degree of deterioration. A support sheet of 10 point buffered folder stock would also be placed within the encapsulation packet. The buffered board would provide structural support for the album pages, and act as a buffering agent to counteract the acidic nature of the album paper. The static charge created by the Mylar encapsulation would be sufficient to consolidate broken album pages together, alleviating the need for an adhesive backing. Pages that remain intact or would otherwise be unsuitable for encapsulation (cockled page for example) would be hinged to a support sheet of 10 point buffered folder stock. Again, the buffered board would act as a buffering agent to counteract the acidic nature of the album paper, but would also allow future researchers to use the support board as a means to access the page, rather than the page itself. Album pages would be hinged using Japanese tissue and methylcellulose. Additionally, the current post-binding structure of the albums is not suitable, and is placing a great deal of stress on the album pages. All album pages would be removed from their current post-binding structure, numbered to retain original order, and re-housed in a custom container. Option 1 would retain the informational value of the albums, and allow for the continued function of the albums as visual indices to sub series RG 1-112-2, while preserving to the extent possible the artifactual value of the original object.

The 2013 album survey identified 32 of the 60 albums in "stable" condition, with no torn or separated pages. These albums do not currently warrant encapsulation or hinging, however preventative measures should be taken to minimize future deterioration from reaching the levels of the other albums. Albums listed in "stable" condition would be removed from their post-bindings, interleaved with MicroChamber tissue paper, and rehoused in a custom container. In consultation with the Archives of Ontario Conservator, it is suggested that interleaving tissue could be placed at a frequency of every 10-15 pages, rather than needing to interleave every page.

Estimated costs for Option 1 are approximately $\$ 0.91$ per page, or $\$ 98$ per album. Based on the 2013 survey 23 albums were identified as "poor" condition and requiring immediate preservation treatment, for a total cost of $\$ 2,260$. Three albums identified as "fair" condition and suitable for treatment as resources are available, along with the 32 albums identified as "stable" condition, would be interleaved with MicroChamber paper at a cost of approximately $\$ 4$ per album or $\$ 140$. Re-housing costs for all albums would cost approximately $\$ 20$ per album or $\$ 1,200$. Grand total for Option 1 would be approximately $\$ 3,600$.

Option 2 - Digital reformatting

Option 2 consists of reformatting the albums into a digital format through the use of a 
$35 \mathrm{~mm}$ digital single-lens-reflex camera and overhead copy stand. Individual album pages would be captured to recreate the experience of viewing the original object as closely as possible. Additional images of individual photographs could also be taken to provide detail images. Images would be archived using the TIFF image format.

Option 2 is not recommended for several factors. Because of the number and size of the $\mathrm{CAB}$ albums, cost is a significant factor in evaluating preservation options. Digitization of albums would require an average of $8 \mathrm{~GB}$ of server space per album or approximately 480GB for all 60 albums. Current server costs for the Archives of Ontario are $\$ 1 / \mathrm{GB} /$ month, resulting in a total cost of $\$ 480$ per month, and an annual cost of $\$ 5,760$. This figure only accounts for a single image of each album page; additional detail images of each photograph would raise the total cost of server storage significantly. Additional costs would also be associated with the continued storage of the physical albums in addition to the digital files. Digitization also does nothing to preserve the albums, which will continue to deteriorate without intervention.

\section{Option 3 - Facsimile copy}

Option 3 consists of creating a facsimile reproduction of the album. This option is not recommended based on costs, effectiveness, time required to perform treatment, and because the treatment is outside of the scope of the PPCM program. Construction of a facsimile album would require the removal of photographs from the original album pages prior to affixing them to new pages. This would be a time-consuming process with indeterminate effectiveness. Assembly of the original albums utilized a mix of heatactivated dry-mount tissue, and rubber cement. The majority of photographs are accompanied by typewritten or hand-written captions that would need to be removed and re-affixed, or transcribed manually. Several pages contain stamps or other inscriptions that would need to be transferred as well to maintain the original context of the album. Additionally, the majority of the work required falls beyond the scope of the PPCM program, necessitating the assistance of a trained conservator.

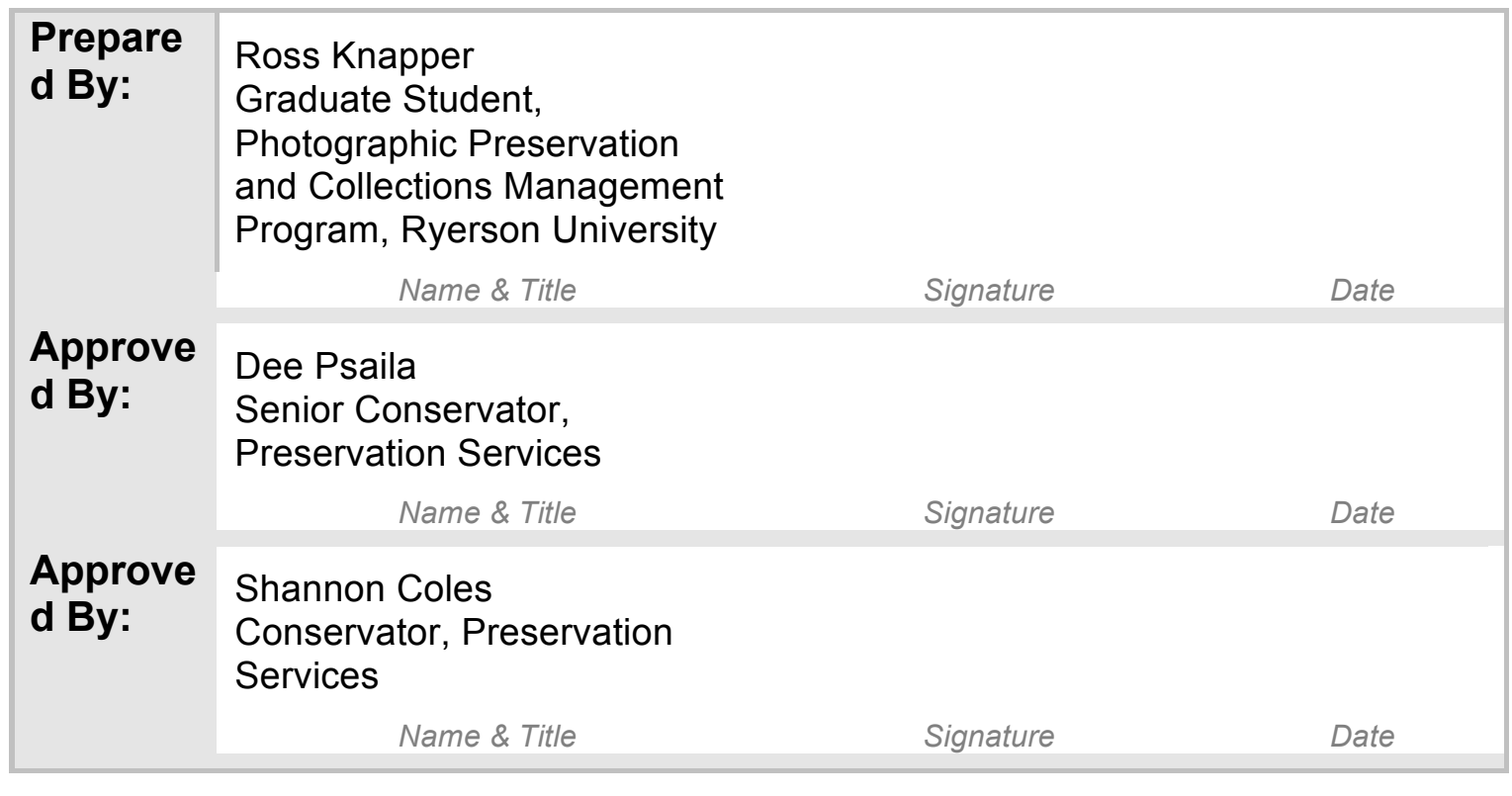

Business Case - Page 4 
Appendix A - Results of March 2000 Album Survey

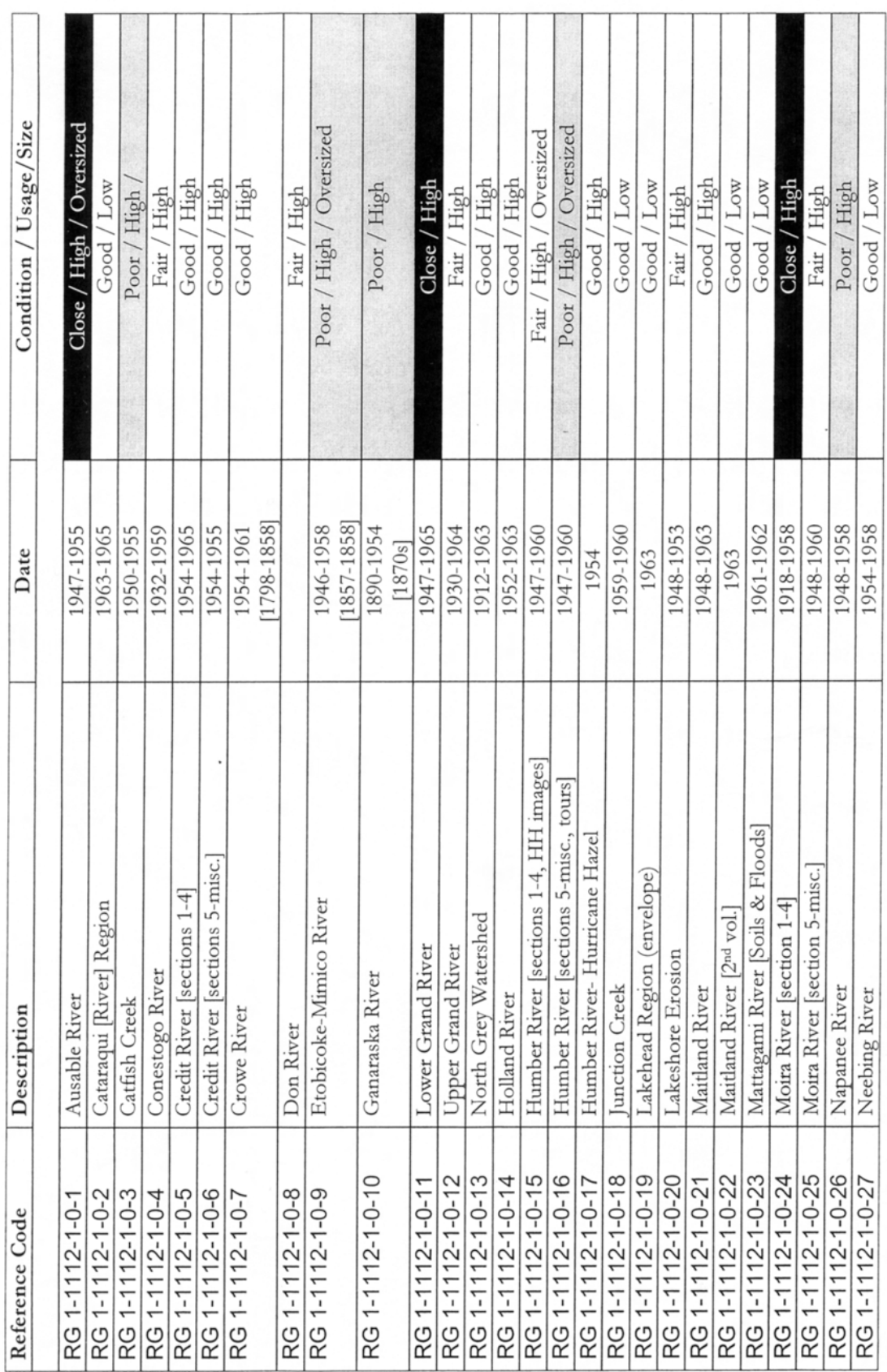

Business Case - Page 5 


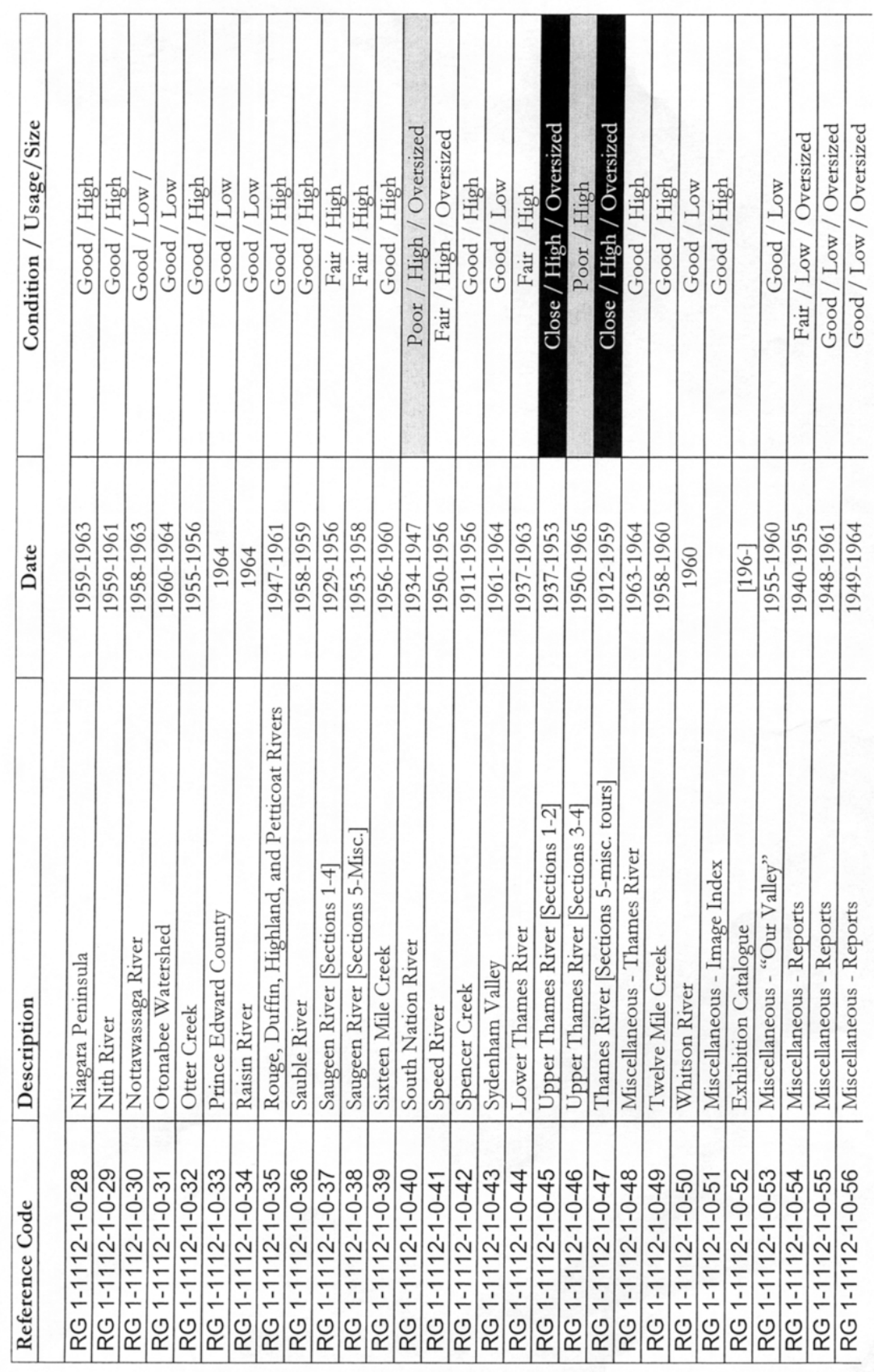

Business Case - Page 6 


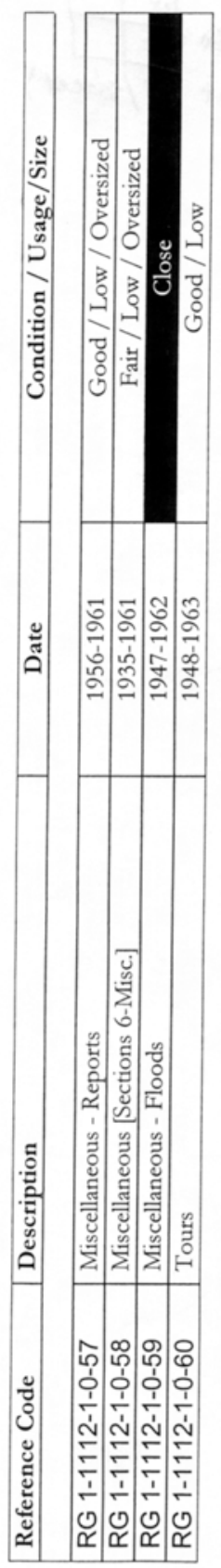

Business Case - Page 7 


\section{Appendix B - Results of the February 2013 Album Survey}

\begin{tabular}{|c|c|c|c|c|}
\hline Reference Code & Album Title & Barcode & Container \# & Condition \\
\hline RG 1-112-1-0-1 & Ausable River & D011516 & E 237 & Poor \\
\hline RG 1-112-1-0-2 & $\begin{array}{l}\text { Cataraqui [River] } \\
\text { Region }\end{array}$ & D011519 & E 278 & Stable \\
\hline RG 1-112-1-0-3 & Catfish Creek & D011517 & E 246 & Poor \\
\hline RG 1-112-1-0-4 & Conestogo River & D011520 & E 365 & Poor \\
\hline RG 1-112-1-0-5 & $\begin{array}{l}\text { Credit River [sections } \\
1-4]\end{array}$ & D011523 & E 254 & Stable \\
\hline RG 1-112-1-0-6 & $\begin{array}{l}\text { Credit River [sections } \\
\text { 5-mis.] }\end{array}$ & D011524 & E 255 & Stable \\
\hline RG 1-112-1-0-7 & Crowe River & D011518 & E 274 & Stable \\
\hline RG 1-112-1-0-8 & Don River & B427430 & D 215 & Poor \\
\hline RG 1-112-1-0-9 & Etobicoke-Mimco River & D011522 & E 235 & Poor \\
\hline RG 1-112-1-0-10 & Ganaraska River & D011521 & E 206 & Poor \\
\hline RG 1-112-1-0-11 & Lower Grand River & D011556 & E 247 & Poor \\
\hline RG 1-112-1-0-12 & Upper Grand River & D011557 & E 248 & Poor \\
\hline RG 1-112-1-0-13 & North Grey Watershed & D011530 & Е 258 & Stable \\
\hline RG 1-112-1-0-14 & Holland River & D011529 & E 252 & Stable \\
\hline RG 1-112-1-0-15 & $\begin{array}{l}\text { Humber River } \\
\text { [sections 1-4] }\end{array}$ & D011525 & E 238 & Poor \\
\hline RG 1-112-1-0-16 & $\begin{array}{l}\text { Humber River } \\
\text { [sections 5-mis., tours] }\end{array}$ & D011527 & E 239 & Poor \\
\hline RG 1-112-1-0-17 & $\begin{array}{l}\text { Humber River } \\
\text { [Hurricane Hazel] }\end{array}$ & D011526 & E 240 & Stable \\
\hline RG 1-112-1-0-18 & Junction Creek & D011531 & E 260 & Stable \\
\hline RG 1-112-1-0-19 & $\begin{array}{l}\text { Lakehead Region } \\
\text { [envelope] }\end{array}$ & D011534 & E 280 & Stable \\
\hline RG 1-112-1-0-20 & Lakeshore Erosion & D011533 & E 272 & Poor \\
\hline RG 1-112-1-0-21 & Maitland River & D011528 & E251 & Stable \\
\hline RG 1-112-1-0-22 & Maitland River [Vol. 2] & D011532 & E 271 & Stable \\
\hline RG 1-112-1-0-23 & $\begin{array}{l}\text { Mattagami River [Soils } \\
\text { \& Floods] }\end{array}$ & D011565 & E 270 & Stable \\
\hline RG 1-112-1-0-24 & $\begin{array}{l}\text { Moira River [sections } \\
1-4 \text { ] }\end{array}$ & D011536 & E 242 & Poor \\
\hline RG 1-112-1-0-25 & $\begin{array}{l}\text { Moira River [sections } \\
\text { 5-misc.] }\end{array}$ & D011535 & E 241 & Fair \\
\hline RG 1-112-1-0-26 & Napanee River & D011537 & Е 243 & Poor \\
\hline RG 1-112-1-0-27 & Neebing River & D011540 & E 256 & Stable \\
\hline RG 1-112-1-0-28 & Niagara Peninsula & D011563 & E 259 & Stable \\
\hline RG 1-112-1-0-29 & Nith River & D011538 & Е 249 & Poor \\
\hline RG 1-112-1-0-30 & Nottawassaga River & D011543 & Е 275 & Poor \\
\hline RG 1-112-1-0-31 & Otonabee Watershed & D011542 & E 261 & Stable \\
\hline
\end{tabular}




\begin{tabular}{|c|c|c|c|c|}
\hline RG 1-112-1-0-32 & Otter Creek & D011541 & E 257 & Stable \\
\hline RG 1-112-1-0-33 & Prince Edward County & D011548 & Е 267 & Stable \\
\hline RG 1-112-1-0-34 & Raisin River & D011549 & Е 268 & Stable \\
\hline RG 1-112-1-0-35 & $\begin{array}{l}\text { Rouge, Duffin, } \\
\text { Highland, and Petticoat } \\
\text { Rivers }\end{array}$ & D011547 & Е 253 & Stable \\
\hline RG 1-112-1-0-36 & Sauble River & D011573 & E 507 & Stable \\
\hline RG 1-112-1-0-37 & $\begin{array}{l}\text { Saugeen River } \\
\text { [sections 1-4] }\end{array}$ & D011546 & Е 244 & Fair \\
\hline RG 1-112-1-0-38 & $\begin{array}{l}\text { Saugeen River } \\
\text { [sections 5-misc.] }\end{array}$ & D011544 & Е 245 & Stable \\
\hline RG 1-112-1-0-39 & Sixteen Mile Creek & D011574 & E 508 & Stable \\
\hline RG 1-112-1-0-40 & South Nation River & D011551 & E 236 & Poor \\
\hline RG 1-112-1-0-41 & Speed River & D011552 & E 250 & Poor \\
\hline RG 1-112-1-0-42 & Spencer Creek & D011545 & E 234 & Stable \\
\hline RG 1-112-1-0-43 & Sydenham Valley & D011550 & Е 273 & Stable \\
\hline RG 1-112-1-0-44 & Lower Thames River & D011559 & Е 263 & Poor \\
\hline RG 1-112-1-0-45 & $\begin{array}{l}\text { Upper Thames River } \\
\text { [sections 1-2] }\end{array}$ & D011553 & Е 207 & Poor \\
\hline RG 1-112-1-0-46 & $\begin{array}{l}\text { Upper Thames River } \\
\text { [sections 3-4] }\end{array}$ & D011555 & Е 266 & Poor \\
\hline RG 1-112-1-0-47 & $\begin{array}{l}\text { Upper Thames River } \\
\text { [sect. 5-misc., tours] }\end{array}$ & D011554 & Е 233 & Poor \\
\hline RG 1-112-1-0-48 & $\begin{array}{l}\text { Miscellaneous - } \\
\text { Thames River }\end{array}$ & D011560 & Е 264 & Stable \\
\hline RG 1-112-1-0-49 & Twelve Mile Creek & D011558 & E 279 & Stable \\
\hline RG 1-112-1-0-50 & Whitson River & D011564 & Е 262 & Stable \\
\hline RG 1-112-1-0-51 & $\begin{array}{l}\text { Miscellaneous - Image } \\
\text { Index }\end{array}$ & D011566 & Е 276 & Stable \\
\hline RG 1-112-1-0-52 & Exhibition Catalogue & D011572 & E 367 & Stable \\
\hline RG 1-112-1-0-53 & $\begin{array}{l}\text { Miscellaneous - "Our } \\
\text { Valley" }\end{array}$ & D011562 & Е 269 & Stable \\
\hline RG 1-112-1-0-54 & $\begin{array}{l}\text { Miscellaneous - } \\
\text { Reports }\end{array}$ & D011567 & Е 285 & Stable \\
\hline RG 1-112-1-0-55 & $\begin{array}{l}\text { Miscellaneous - } \\
\text { Reports }\end{array}$ & D011569 & Е 284 & Stable \\
\hline RG 1-112-1-0-56 & $\begin{array}{l}\text { Miscellaneous - } \\
\text { Reports }\end{array}$ & D011570 & Е 283 & Stable \\
\hline RG 1-112-1-0-57 & $\begin{array}{l}\text { Miscellaneous - } \\
\text { Reports }\end{array}$ & D011568 & Е 282 & Fair \\
\hline RG 1-112-1-0-58 & Miscellaneous & D011561 & E 265 & Poor \\
\hline RG 1-112-1-0-59 & Miscellaneous - Floods & D011539 & Е 281 & Poor \\
\hline RG 1-112-1-0-60 & Tours & D011571 & E 366 & Poor \\
\hline
\end{tabular}




\section{Appendix C - Ausable Creek Album (RG 1-112-1-0-1)}

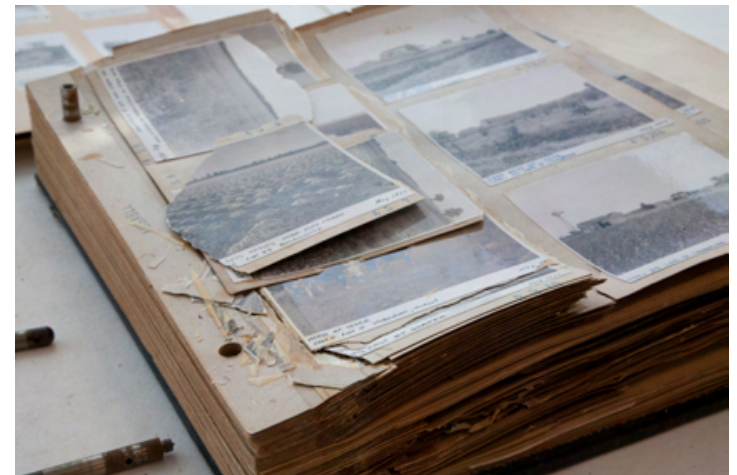

RG 1-112-1-0-1 Ausable Creek

View of broken pages and page fragments

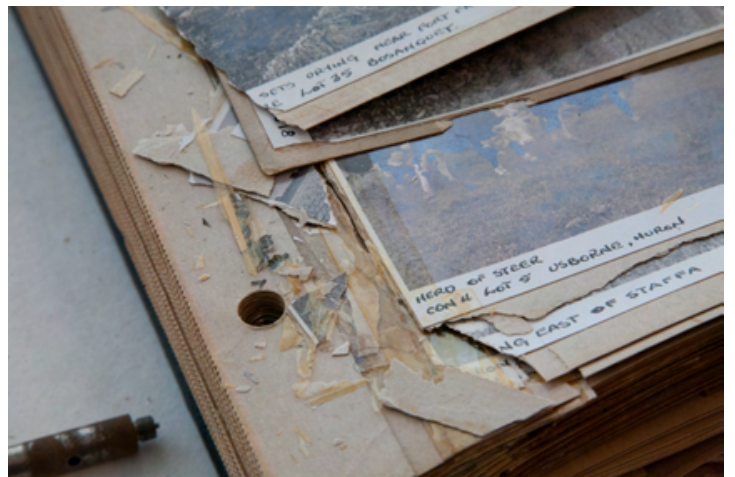

RG 1-112-1-0-1 Ausable Creek Close up of page fragments

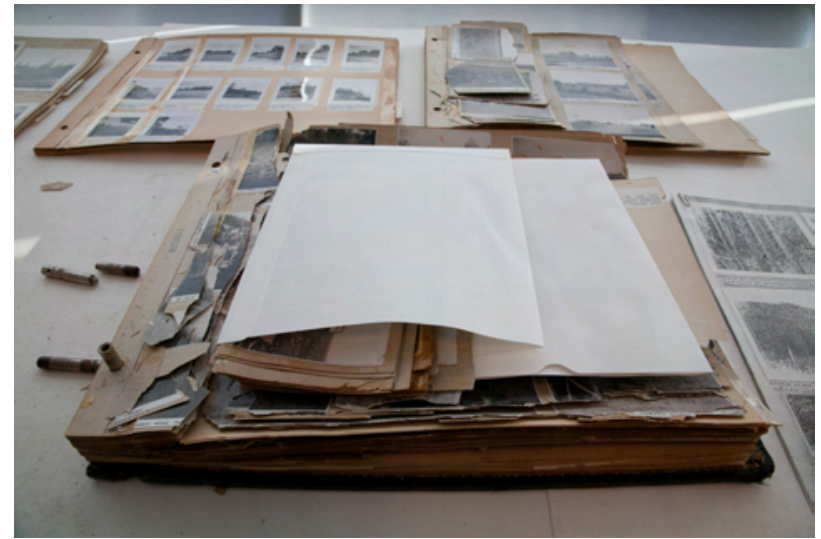

RG 1-112-1-0-1 Ausable Creek Envelopes placed in middle of album containing broken pages

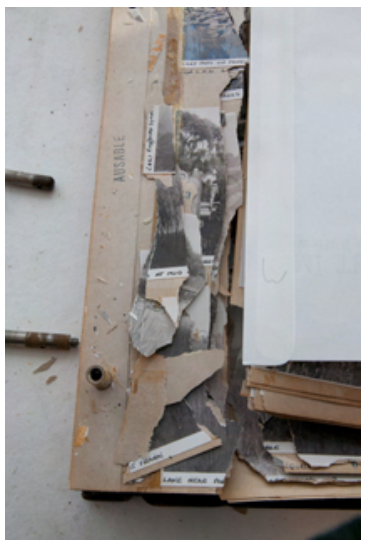

RG 1-112-1-0-1 Ausable Creek Close up of paper fragments 
Appendix E:

Flowchart for determining page treatment 
Flowchart for CAB photograph album treatment

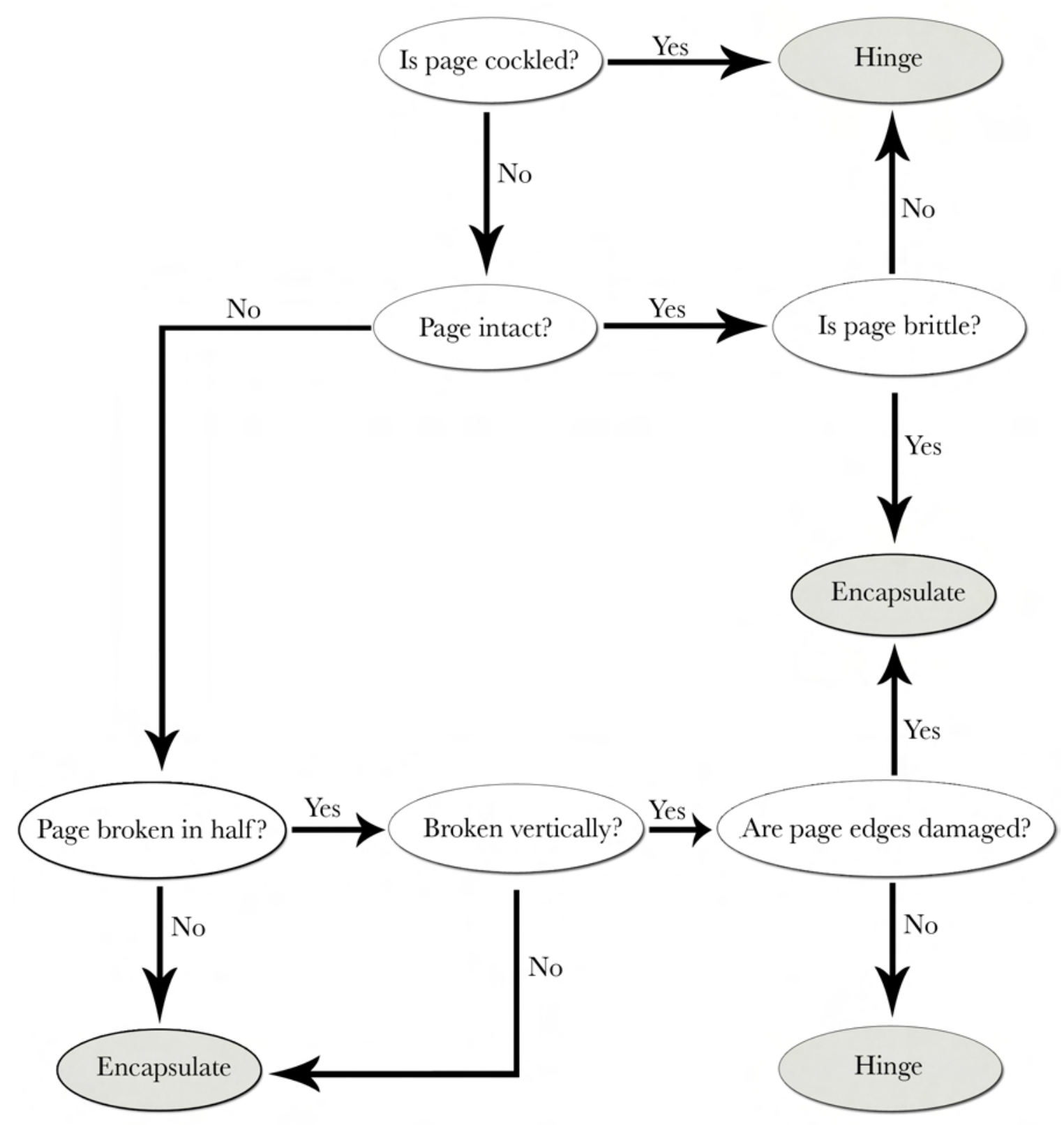


Appendix F:

Preparation of methyl cellulose 


\section{Instructions for preparing of methyl cellulose}

1. Determine the appropriate concentration (grams per liter) of methyl cellulose required. A $5 \%$ concentration of methyl cellulose is used for hinging the CAB photograph albums.

2. Weigh out 5 grams of methyl cellulose powder. Place powder in an appropriately sized container that has a lid.

3. Measure out $100 \mathrm{ml}$ of distilled water.

4. Heat $25 \mathrm{ml}$ of water to about 80-90 degrees Celsius (hot, but not boiling). Chill the remaining $75 \mathrm{ml}$ of water till cold.

5. Mix the methyl cellulose powder with the hot water, stirring briskly to prevent or break up any lumps. Once powder has evenly dispersed, add the cold water. Gover and allow to sit for several hours or overnight.

6. To use, place a small amount of methyl cellulose from the supply container into a working container using a clean utensil. Never work from the main supply container or dip used utensils into the supply container. 
Appendix G:

List of materials and suppliers 
The following is a list of materials used in the treatment of the CAB photograph albums, along with a partial list of suppliers and manufacturers. Alternative materials where applicable have also been given. Contact information for suppliers and manufacturers can be located below.

\begin{tabular}{|c|c|c|c|c|}
\hline \multicolumn{5}{|l|}{ Material and supplier list } \\
\hline \multirow[t]{2}{*}{ Product } & \multicolumn{4}{|c|}{ Supplier or manufacturer } \\
\hline & Talas & $\begin{array}{l}\text { Gaylord } \\
\text { Brothers }\end{array}$ & $\begin{array}{c}\text { Carr } \\
\text { Mclean }\end{array}$ & $\begin{array}{c}\text { Sabic } \\
\text { Polymershapes }\end{array}$ \\
\hline Polyester film & $\mathrm{X}$ & $\mathrm{X}$ & $\mathrm{X}$ & $\mathrm{X}$ \\
\hline Folder stock & $\mathrm{X}$ & $\mathrm{X}$ & $\mathrm{X}$ & \\
\hline Ultrasonic welder & \multicolumn{4}{|c|}{ See ultrasonic welder manufacturer list below } \\
\hline 3M 415 double stick tape & $\mathrm{X}$ & $\mathrm{X}$ & & \\
\hline Japanese tissue & $\mathrm{X}$ & & $\mathrm{X}$ & \\
\hline $\begin{array}{r}\text { Alternatives to using Fapanese } \\
\text { tissue for hinging }\end{array}$ & \multicolumn{4}{|c|}{$\begin{array}{l}\text { Note: many of these alternatives are self-adhesive. The } \\
\text { reversibility of pressure sensitive tapes is not guaranteed or } \\
\text { requires the use of solvents, and should be used with care. }\end{array}$} \\
\hline Tengujo tape (not self adhesive) & $\mathrm{X}$ & & & \\
\hline $\begin{array}{r}\text { Lineco Hayaku Fapanese } \\
\text { hinging tape }\end{array}$ & $\mathrm{X}$ & $\mathrm{X}$ & $\mathrm{X}$ & \\
\hline Filmoplast P90 & $\mathrm{X}$ & $\mathrm{X}$ & $\mathrm{X}$ & \\
\hline Methyl cellulose & $\mathrm{X}$ & $\mathrm{X}$ & $\mathrm{X}$ & \\
\hline B-flute corrugated board & $\mathrm{X}$ & $\mathrm{X}$ & $\mathrm{X}$ & \\
\hline
\end{tabular}

\section{Material suppliers}

\section{Carr McLean}

461 Horner Avenue

Toronto, Ontario M8W 4X2

Website: www.carrmclean.ca

Phone: 800-268-2123 (Canada)

$$
\text { 416-252-337 } 1 \text { (International) }
$$

Email: sales@carrmclean.ca 
Gaylord Brothers

PO Box 4901

Syracuse, New York 13221-4901

Website: www.gaylord.com

Phone: 800-962-9580 (US) 800-841-5854 (Canada) 315-634-8243 (International)

Email: customerservice@gaylord.com

Sabic Polymershapes

9150 Airport Road

Brampton, Ontario L6S 6G1

Telephone: 905-789-3100 (Local)

Telephone: 800-268-0610 (Toll free)

Talas

330 Morgan Avenue

Brooklyn, New York 11211

Website: talasonline.com

Phone: 212-219-0770

\section{Ultrasonic welder manufacturers}

ArcProtec, Inc. (Canadian distributor for Conservation Resources International, Inc.)

P.O. Box 2506, Station D

Ottawa, Ontario K1P 5W6

Telephone: 613-523-9260

Conservation Resources International, Inc.

5532 Port Royal Road

Springfield, Virginia 22151

Website: www.conservationresources.com

Telephone: 800-634-6932

Email: sales@conservationresources.com

Transilwrap du Canada Ltée

131 Barre Street

Ville St-Laurent, Québec H4T 1W6

Telephone: 514-735-5535

William Minter

3605 North Damen Avenue

Chicago, Illinois 60618

Telephone: 312-248-0624 


\section{Bibliography}

American Institute for Conservation Book and Paper Group. "Chapter 20 Alkalization and Neutralization." Paper Conservation Catalog (1988). Accessed January 13, 2013. http://cool.conservation-us.org/coolaic/sg/bpg/pcc/20_neutralization.pdf.

_ "Chapter 29 Lining." Paper Conservation Catalog (1988). Accessed January 13, 2013. http://cool.conservation-us.org/coolaic/sg/bpg/pcc/29_lining.pdf.

- "Chapter 46 Adhesives." Paper Conservation Catalog (1988). Accessed January 13, 2013. http://cool.conservation-us.org/coolaic/sg/bpg/pcc/46_adhesives.pdf.

Arizona State Library, Archives and Public Records. "Preservation." Accessed November 13, 2012. http://www.azlibrary.gov/cdt/preser.aspx.

Balloffet, Nelly. Preservation and Conservation for Libraries and Archives. Chicago: American Library Association, 2005.

Baty et al. "Deacidification for the Conservation and Preservation of Paper-based Works: A Review." BioResources, Vol. 5, No. 3 (2010): 1955-2023. Accessed February 22, 2013. http://www.ncsu.edu/bioresources/BioRes_05/BioRes_05_3_1955_Baty_MMHJ_Deac idification_Conserv_Paper_Review_972.pdf.

Beaudoin, Joan E. "Context and Its Role in the Digital Preservation of Cultural Objects." D-Lib Magazine, Volume 18, Number 11/12 (November/December 2012). Accessed November 28, 2012. doi:10.1045/november2012-beaudoin1

Canadian Conservation Institute. "Encapsulation.” Accessed February 22, 2013. http://www.cci-icc.gc.ca/publications/notes/11-10-eng.aspx.

Conway, Paul. "Modes of Seeing: Digitized Photographic Archives and the User Experienced User." The American Archivist, Vol. 73 (Fall / Winter 2010): 425-462.

Conway, Paul, and Ricardo Punzalan. "Fields of Vision: Toward a New Theory of Visual Literacy for Digitized Archival Photographs." Archivaria 71 (Spring 2011): 63-97.

Cornell University Library. "Polyester film encapsulation." Accessed February 22, 2013. http://www.library.cornell.edu/preservation/librarypreservation/preservation/basicrem edialld.htm.

Craven, Louise, ed. What Are Archives? Cultural and Theoretical Perspectives: A Reader. Burlington: Ashgate, 2008.

DeCandido, Robert. Collections Conservation. Washington, D.C.: Association of Research Libraries, 1993. 
Downey, Laura. "Images of the Southwest: A Tourist Album." In Conservation of Scrapbooks and Albums. Postprints of the Book and Paper Group and Photographic Materials Group Foint Session at the $27^{\text {th }}$ Annual Meeting of the American Institute for Conservation of Historic and Artisitic Works, 312. Washington, D.C.: AIC, 2000.

Duff, Wendy, Barbara Craig, and Joan Cherry. "Finding and Using Archival Resources: A Cross-Canada Survey of Historians Studying Canadian History." Archivaria 58 (Fall 2004): 51-80.

Edwards, Elizabeth, and Janice Hart. Introduction to Photographs Objects Histories: On the Materiality of Images, edited by Elizabeth Edwards and Janice Hart, 1-15. New York: Routledge, 2004.

Gladney, Henry M. "Long-Term Preservation of Digital Records: Trustworthy Digital Objects." The American Archivist, Vol. 72 (Fall/Winter 2009): 401-435.

Gunselman, Cheryl. "Assessing Preservation Needs of Manuscript Collections with a Comprehensive Survey.” The American Archivist, Vol. 70 (Spring/Summer 2007): 151-169.

Havermans, John B.G.A. "Ageing behaviour of encapsulated paper.” Restaurator: International Journal for the Preservation of Library and Archival Material, Volume 20, Number 2 (1999): 108-115.

Hill, Gregory. "The Conservation of a Photograph Album at the National Archives of Canada." Fournal of the American Institute for Conservation, Volume 30, Number 1 (1991): 7588.

Horton, Richard W. "Glossary of Terms Relating to Photo Albums." In Conservation of Scrapbooks and Albums. Postprints of the Book and Paper Group and Photographic Materials Group Foint Session at the 27th Annual Meeting of the American Institute for Conservation of Historic and Artisitic Works, 3-12. Washington, D.C.: AIC, 2000.

Hunter, Gregory S. Maintaining Practical Archives: A How-to-do-it Manual. 2nd ed. New York: Neal- Schuman Publishers, Inc., 2003.

Keene, Suzanne. "Preserving digital materials: Confronting tomorrow's problems today." The Conservator, 26:1 (2002): 93-99.

Library of Congress. "Preservation of Scrapbooks and Albums." Accessed November 13, 2012. http://cool.conservation-us.org/byauth/zucker/zuckerl.html.

Lozano, Gustavo. "History and Conservation of Albums and Photographically Illustrated Books." Advanced Residency Program in Photograph Conservation, George Eastman House, 2007. 
McCrady, Ellen. "Accelerated Aging and the Effects of Enclosure." Abbey Newsletter, Volume 8, Number 2 (April 1984). Accessed February 2, 2013. http://cool.conservationus.org/byorg/abbey/an/an08/an08-2/an08-208.html.

Minter, William, and John W. Baty. "The Role of Polyester Film Encapsulation - With and Without Prior Deacidification - On Paper Degradation." Paper presented at the $41^{\text {st }}$ annual meeting for the American Institute for Conservation, Indianapolis, Indiana, May 29 - June 1, 2013.

National Park Service. "Polyester Encapsulation.” Accessed November 13, 2012. http://www.nps.gov/museum/publications/conserveogram/13-03.pdf.

Northeast Document Conservation Center. "How to Do Your Own Matting and Hinging." Accessed January 13, 2013. http://www.nedcc.org/freeresources/preservation-leaflets/7.-conservation-procedures/7.4-how-to-do-your-ownmatting-and-hinging.

_. "Repairing Paper Artifacts." Accessed January 13, 2013.

http://www.nedcc.org/free-resources/preservation-leaflets/7.-conservationprocedures/7.3-repairing-paper-artifacts.

Ogden, Sherelyn. "Preservation Options for Scrapbook and Album Formats," in The Book and Paper Group Annual, Vol. 10 (1991). Accessed November 13, 2012.

http://cool.conservation-us.org/coolaic/sg/bpg/annual/v10/bp10-14.html.

Rekrut, Ala. "Material Literacy: Reading Records as Material Culture." Archivaria 60 (Fall 2005): 11-38.

Sassoon, Joanna. "Photographic Materiality in the Age of Digital Reproduction." In Photographs Objects Histories: On the Materiality of Images, edited by Elizabeth Edwards and Janice Heart, 186-202. New York: Routledge, 2004.

Schwartz Joan M. "Negotiating the Visual Turn: New Perspectives on Images and Archives." The American Archivist, Vol. 67 (Spring/Summer 2004): 107-122.

Teper, Jennifer Hain. "An Introduction to Preservation Challenges and Potential Solutions for Scrapbooks in Archival Collections." Journal of Archival Organization, Volume 5, Issue 3 (2007): 47-64. 